\title{
Contextual attributes impacting the effectiveness of requirements elicitation Techniques: Mapping theoretical and empirical research
}

\author{
Dante Carrizo ${ }^{\mathrm{a}, *}$, Oscar Dieste ${ }^{\mathrm{b}}$, Natalia Juristo ${ }^{\mathrm{c}}$ \\ a University of Atacama, Avda Copayapu 485, Copiapó, Chile \\ ${ }^{\mathrm{b}}$ Technical University of Madrid, Boadilla del Monte, Madrid 28660, Spain \\ ${ }^{c}$ University of Oulu, Ouh, Finland
}

\section{A B S T R A C T}

Background: Software engineers can utilise a myriad of elicitation techniques to capture relevant informa- tion in order to specify requirements. The effectiveness of these techniques varies depending on the con- text in which the elicitation takes place. So, it is important to identify the attributes that represent this context. Objective: This paper aims to match theoretical to empirical research on contextual attributes that influence elicitation technique effectiveness. Method: We conduct a systematic mapping study to identify proposed attributes (by theoretical works) and attributes studied empirically. Then we map empirical re- sults with theoretical proposals. Results: $60 \%$ of theoretically proposed attributes have been studied em- pirically. There seems to be some degree of coordination between theory and empiricism. However, there is empirical confirmation of the impact of only a third of the theoretically proposed attributes. Conclu- sions: These results call for more empirical research in order to evaluate beliefs with respect to elicitation techniques.

\section{Introduction}

Software requirements are often elicited by means of interviews $[1,2]$. However, more elicitation techniques are likely to be necessary to gather the full range of requirements for most software systems. There are a variety of elicitation techniques that can be used. Some reviews account for tens of elicitation techniques [35]. Many of these techniques have been imported from fields like cognitive psychology, anthropology, sociology and linguistics [6].

Elicitation techniques are of different kinds [7], and they may therefore be more effective in some situations than in others. Each type of problem, development team or stakeholder group outlines a context that fits, to a greater or lesser degree, the conditions under which certain elicitation techniques get its highest performance. The contextual attributes describe such conditions. Contextual attributes characterise aspects of the environment in which the elicitation process takes place, such as characteristics of participants or problem. The values of the contextual attributes may or may not match the characteristics required by the elicitation techniques, determining whether or not they are suitable for use

\footnotetext{
* Corresponding author.

E-mail addresses: dante.carrizo@uda.cl (D. Carrizo), odieste@fi.upm.es (O. Dieste), natalia.juristo@oulu.fi (N. Juristo).
}

in a particular situation. For instance, if there is a set of stakeholders, group techniques fit better; People per Session is a contextual attribute. Such contextual attribute assesses whether exist groups or individuals and the matching between context conditions (number of stakeholders) and technique adequacy (appropriate for group conditions) allows to choose the most promising elicitation technique. If there are different points of view among stakeholders, techniques that facilitate convergence will be more appropriate; Consensus among informants is the attribute that describes whether in the context exist agreement or not across stakeholders. Again matching among context conditions and contextual attributes identifies appropriate techniques. If stakeholders have difficulty expressing their thinking, structured techniques will perform better, and the contextual attribute Articulability allows to identify such context condition. If the elicitor has low experience, simpler techniques may be more suitable, since contextual attributes such as Elicitation Experience or Experience with Elicitation Techniques allow to match techniques suitable for the condition elicitor's low experience. If the problem domain is complex, cognitive techniques may work while others do not, and so on. In other words, some contextual attributes of the project may influence the behaviour of elicitation techniques, and thus their effectiveness [8]. So, it is critical to understand which values of contextual attributes get the best of a technique. For example, the open 
interview will perform well for gathering information in the form of declarative knowledge. However, eliciting procedural knowledge using open interview will get poorer results that using protocol analysis, since this last technique was envisaged to elicit such type of knowledge [9].

The influence of the context on the effectiveness of the elicitation techniques has been repeatedly discussed in the requirements literature [8,10-14]. We call effectiveness a measure of the performance of techniques in capturing more and better information (per elicitation session). For example, if in a given situation the technique questionnaire gathers more requirements unambiguous, complete and verifiable than the technique open interview, then questionnaire is more effective than open interview for the specific conditions of such situation, although in other situation (with other conditions) open interview will be more effective than questionnaire. The claims about with regard to which technique is better suited to a particular context often rely on the experience and knowledge acquired by each researcher. Few claims have been empirically evaluated by means of experiments comparing the behaviour of elicitation techniques in different contexts [15].

Which contextual attributes may influence the effectiveness of elicitation techniques is a need on two grounds: (1) frameworks and procedures for selecting the most effective elicitation technique for an elicitation session, (2) knowledge on the contextual attributes, irrespective of whether or not they have an influence, provides directions for empirical research. This first ground was the aim of our previous research [16], which proposed a technique selection framework based on the most promising contextual attributes from both an operational viewpoint and in regard to consensus in the requirements engineering community.

In the research reported here, we address the second of the grounds mentioned above, that is, we conduct a literature review in order to empirically confirm the influence of contextual attributes on the effectiveness of elicitation techniques. We have reviewed contextual attributes impacting the effectiveness of elicitation techniques that have been studied empirically and proposed in theoretical research.

In short, our research identifies all contextual attributes discussed in the literature and checks which theoretical and empirical studies have addressed such contextual attributes. We aim to understand how well aligned theory and empiricism are in requirements elicitation and to identify the beliefs with respect to the effectiveness of elicitation techniques that have not yet been empirically evaluated. To do so, we use the systematic mapping study method.

The results suggest that there are 27 contextual attributes addressed in 26 theoretical works and 28 empirical studies. Almost half of the contextual attributes proposed theoretically, as having an influence on elicitation technique effectiveness, still require empirical research to verify whether or not they have a bearing. There was strong confirmation of the influence of nine out of 27 contextual attributes. So, more empirical research needs to be undertaken to provide practitioners with guidelines based on empirical evidence about which elicitation technique select.

There are very few empirical studies per technique and attribute. Therefore, we have not been able to focus on individual elicitation techniques, as there is not enough empirical evidence to perform a matching of attributes to techniques. We have focused on attributes having an individual impact on any technique since at such level there is barely information enough.

In the rest of this paper, Section 2 discusses the background of this research. Section 3 describes the design of the mapping study. Section 4 reports the primary studies found. Section 5 uses the extracted data to answer the research questions. Section 6 discusses the findings of our work. The limitations of the study are described in Section 7. Finally, Section 8 outlines the conclusions.

\section{Related work}

There are no previous systematic mapping studies analysing theoretical and empirical works on contextual attributes influencing requirements elicitation. The systematic review by Dieste and Juristo [15] is the only review that reference the attributes addressed in empirical studies. That paper takes into consideration only the empirical studies for the purpose of evidence aggregation. However, contextual attributes are explicitly mentioned, although possibly not with this name, in several proposals for selecting requirements elicitation techniques. These proposals are generally based on comparing technique characteristics and context characteristics.

Maiden and Rugg [17] presented a framework for selecting elicitation techniques which matches 12 techniques with six facts or attributes, such as purpose of requirements, internal filtering of knowledge, knowledge types, observable phenomena, acquisition context and method interdependencies.

Hickey and Davis [18] built two ontologies for matching purposes: one characterises the requirements elicitation techniques and the other characterises the context in which this activity takes place. The first ontology defines ten dimensions: physical colocation, temporal co-location, record-keeping, analyst role, convergence/divergence, anonymity, stakeholder count, tool based, product/human focus and direct/indirect. The second defines about twenty characteristics of the problem domain, solution domain, stakeholders, solution builders and bridge-builders.

Batista and Carvalho [19] proposed a set of 11 parameters or attributes to characterise the contexts for which the requirements elicitation techniques are best suited and reported matches for three techniques. The proposed parameters attributes are: stakeholder role, application categories, organizational environment, requirements source, techniques applicable in different phases, developer's technique training/knowledge level, required developer skills, cost of the technique, purpose of the gathered information, quantity of gathered information, and user participation level.

We conducted an opportunistic search of attributes for the purpose of instantiating the proposed elicitation technique selection framework [16]. The attributes proposed in that work had to meet the requirements of theoretical justifiability (possibility of finding a justification for the attribute influencing elicitation technique effectiveness), instrumentability (possibility of assigning a value to the attribute during a development project), and assessability (possibility of establishing ratings for the different attribute values). We also proposed new attributes that, we believe, influence elicitation technique selection.

Besides from the above proposals, several papers in the requirements field state contextual attributes and surmise what influence they have on elicitation technique effectiveness. For example, a characteristic like ability to improve communication, as a property of some technique, does not provide any clear indication as to the conditions under which it can be used. On the other hand, the contextual attribute problems of communication among participants [20] can be used to decide which techniques will be best: interview in the case of fluid communication or protocol analysis if the verbalization of tacit knowledge is troublesome.

The stock of contextual attributes used in the above papers, as well as their effect on elicitation techniques is bereft of any empirical groundwork and obeys either the expert opinion of their authors or is based on general literature (e.g., cognitive psychology) or previous research, most of which has no empirical foundation either and can again be regarded as expert opinion.

The evidence gathered from expert opinion based on theory is at the bottom, whereas empirical studies are at the top of evidence hierarchies [21]. It is worthwhile, therefore, exploring which contextual attributes have been proposed in theoretical studies and 
the extent to which their influence on elicitation techniques has been confirmed empirically.

\section{Mapping study design}

\subsection{Research questions}

We aim to evaluate the match between theoretical and empirical research with regard to the contextual attributes that play a role in the selection of techniques for an elicitation session. Our research questions are:

RQ1: What contextual attributes have been proposed by theoretical research and/or empirically evaluated by empirical research as influencing the effectiveness of elicitation techniques?

RQ2: Which theoretically proposed attributes have been empirically studied?

RQ3: Which theoretically proposed attributes have been empirically confirmed as having an influence on the effectiveness of elicitation techniques?

RQ4: Have attributes affecting effectiveness of elicitation techniques been sufficiently empirically researched?

We have selected systematic mapping as the method for answering the research questions. Systematic mapping studies (SMSs) are an alternative to systematic literature reviews (SLRs) applicable if there is not enough empirical evidence or the topic is too broad for a systematic review to be feasible. The granularity level of a mapping study is coarser, and it aims to identify research gaps and clusters of evidence in order to direct future research [22]. A SLR is a means of identifying, evaluating and interpreting all available empirical research relevant to a particular question focusing on quantitative and empirical studies, while SMS intend to 'map out' the research undertaken rather than to answer a detailed research question. A systematic mapping study structures the type of research reports and results that have been published by categorizing them. It often gives a visual summary, the map, of its results [23].

From the findings of the review by Dieste and Juristo [15], we can presume that it will be difficult to corroborate the influence of contextual attributes for each elicitation technique because there are not enough replications of empirical studies. Only a few empirical works study the same attribute for the same technique. Therefore the appropriate research method here is SMS rather than SLR. Our SMS focuses on attributes, even if studied for different elicitation techniques, since there is not enough evidence to focus our research on attributes impacting a specific technique.

\subsection{Search strategy}

The information pursuit was based on a search of research papers and books related to requirements elicitation techniques. We searched three bibliographic databases with an unspecified start date and an end date of December 2014 (inclusive): Scopus, IEEE Xplore and ACM DL.

The searches accounted for four aspects (linked by AND):

- focus of our research (framework, comparison, study, empirical, experiment, case study, survey),

- research area (requirements, knowledge),

- type of activity (elicitation, acquisition, gathering) and

- type of instrumentation (techniques, methods).

- The strings used to search the specified databases were:

- Scopus: TITLE-ABS-KEY((framework OR comparison OR empirical OR study OR experiment OR case study OR survey) AND (requirements OR knowledge) AND (elicitation OR acquisition OR gathering) AND (techniques OR methods)) AND SUBJAREA (comp OR Undefined)
- IEEE Xplore: Metadata: ((framework OR comparison OR empirical OR study OR experiment OR case study OR survey) AND (requirements OR knowledge) AND (elicitation OR acquisition OR gathering) AND (techniques OR methods)) AND SUBJECT: Computing \& Processing (Hardware/Software)

- ACM DL: ((Title:framework OR Title;comparison OR Title:empirical OR Title:study OR Title:experiment OR Title:case study OR Title:survey) AND (Title:requirements OR Title:knowledge) AND (Title:elicitation OR Title:acquisition OR Title:gathering) AND (Title:techniques OR Title:methods))OR ((Abstract:framework OR Abstract:comparison OR Abstract:empirical OR Abstract:study OR Abstract:experiment OR Abstract:case study OR Abstract:survey) AND (Abstract:requirements OR Abstract:knowledge) AND (Abstract:elicitation OR Abstract:gathering) AND (Abstract:techniques OR Abstract:methods)).

Apart from these formal searches, we applied backward snowballing (i.e. searching based on the references listed in the retrieved papers) and opportunistic searches of grey literature.

\subsection{Inclusion/exclusion criteria}

To identify relevant papers, we took into account the following aspects considered as inclusion criteria:

- Although the focus is on SE elicitation techniques, we included studies on other areas where elicitation techniques are applied (like economics or marketing). This, since we aim to study the performance of the technique itself regardless of the use of tools in the application of a technique. Additionally, the techniques may be individual or group, that is, we included techniques used to elicit information from both one and more than one stakeholder.

- The focus is on attributes that are related to the elicitation process. Some of the attributes proposed in the literature may influence other requirements activities but not elicitation. For example, the requirements volatility and number of requirements attributes cannot be established until after the requirements have been captured, and therefore their influence is confined to post-elicitation activities, such as requirements specification and management [24].

- Empirical studies may measure the effectiveness of elicitation techniques differently [15]. Such diverse measurements of technique adequacy may have a bearing on the aggregation of the results of the experiments but is not critical for deciding whether an attribute is capable of differentiating techniques, that is, irrespective of how the effectiveness of the elicitation techniques is measured, a difference in the results of applying the techniques under the attribute conditions is sufficient for it to be considered to have an influence.

We considered exclusion criteria as follows:

- Studies on requirements elicitation support tools, like software for automating elicitation techniques, were not considered because they may endow the evaluated techniques with differentiating features that bias their behaviour, and therefore their effectiveness. The problem with using tools is that the comparison would be unfair: Some techniques do have tools that implement them (even some techniques have several tools), others do not. Then the research would not be any more about which technique intrinsically fits better certain circumstances but about efficiency of the techniques due to the tools that implement it not due to the suitability to the context.

- Studies on elicitation technique characterization, like [3], have generally been excluded as they consider aspects that are intrinsic to, or descriptive or prescriptive of the nature of tech- 


\begin{tabular}{|c|c|c|c|c|c|c|c|}
\hline Factor & $\begin{array}{l}\text { Attributes } \\
\text { (name given } \\
\text { in our } \\
\text { mapping } \\
\text { study) }\end{array}$ & $\begin{array}{l}\text { Study } \\
\text { Type }\end{array}$ & Authors & $\begin{array}{c}\text { Original Name } \\
\text { (name given in } \\
\text { the primary } \\
\text { study) }\end{array}$ & $\begin{array}{l}\text { Attribute } \\
\text { Values } \\
\text { (discussed in } \\
\text { the primary } \\
\text { study) }\end{array}$ & Excerpt/Results & $\begin{array}{c}\text { Primary Study } \\
\text { Category }\end{array}$ \\
\hline & & & & & & & \\
\hline & & & & & & & \\
\hline
\end{tabular}

Fig. 1. Data extraction form.

niques but do not consider aspects of the context in which the techniques can be applied. Such type of works refer to the class of technique, such as, for example, it is "administered orally or in writing" instead of aspects referred to contextual attributes like "whether or not stakeholders are online" [25]. It is the aspects of context, availability or location, that may vary from one elicitation context to another and even between elicitation sessions, whereas the intrinsic characteristics of the techniques are unchanged (mode of questionnaire administration). Even though it is the intrinsic features that underpin the merits and adequacies of technique, they, by themselves, are unable to differentiate whether techniques are adequate for one context or another. A technique will be adequate for a scenario when its intrinsic characteristics fit in with the contextual circumstances of an elicitation session.

- Not all the empirical studies on effectiveness provide useful information for this research. Strictly speaking, we focus on studies that compare more than one elicitation technique and also take into account some condition or contextual attribute as variable. The results of comparative experiments indicate whether technique effectiveness varies, thereby detecting the influence of an attribute. It is impossible to ascertain from a study of a single technique whether the considered attributes make the difference between technique effectiveness. Therefore, they may not necessarily influence the selection of elicitation techniques for a context. For example, Roth and Wood [26] study the Delphi method as a technique for comparing the information gathered from individual and group stakeholders. Although the results showed that more information of better quality is gathered from groups, this relative effectiveness may be similar across all elicitation techniques, meaning that the attribute referred to the number of informants would have no bearing on technique selection, for the case of techniques that can be applied to both individual and group stakeholders.

- Note that a study of the effectiveness of several techniques is out of the scope of research unless it tests a specific contextual attribute [27-30]. For example, Jones, Miles and Read [27] evaluated three knowledge acquisition techniques in order to build a prototype expert system. However, they did not define any contextual variable to study the effect of context on the treatment. It is precisely such context variable that provides the key decision-making information on which technique is likely to be more effective in a particular elicitation session.

\subsection{Data extraction strategy}

Once we identified the primary studies, we proceed to gathering relevant information about the contextual attributes. We defined the data extraction form shown in Fig. 1. Important information is whether the studies are theoretical or empirical.

Theoretical papers discuss the authors' proposals without empirical validation. Most often they are works about models or roadmaps. The main information that we wanted to retrieve from these proposals are:

- Type of proposal

- Frameworks, which group papers dealing with models, methods, approaches and frameworks addressing a wide range of general aspects of the elicitation process.

- Taxonomies, which include typologies, ontologies and taxonomies per se, following a faceted classification.

- Guidelines, which account for comparisons of techniques and guidelines for use.

- Excerpts specifying the argument of authors with respect to the attribute influencing elicitation technique effectiveness.

In the case of empirical studies, our interest focused on the type of method used (experiment, case study, survey, etc.) and the results obtained.

Some papers include both theoretical and empirical studies. In these cases, the studies are catalogued according to the contribution they make to our research. For example, Fowlkes et al. [31] report an empirical study on a single technique: event-based elicitation. As discussed above, this mapping study does not include studies of single techniques. On the other hand, the authors state that some elicitation techniques depend on contextual attributes such as domain knowledge and process time. Thus, for the purposes of our research, we consider this to be a theory paper, as we use the theoretical section of the above paper as a source of information.

Additionally, we had to establish the contextual attribute or attributes that pinpoint the effectiveness of the elicitation techniques, as well as their possible values.

\section{Study execution}

We applied two consecutive filters to each database search in order to select the primary studies. First, we screened the title and abstract of each identified paper (F1: First Filter in Fig. 2) by means of which we were able to reject most of the articles and identify candidates. Later, we scan the full text of the candidate papers to rule out some papers and leave the selected primary studies (F2: Second Filter in Fig. 2).

As shown in Fig. 2, Scopus search and backward snowballing were the most productive screenings, as most of the studies of interest were identified there. We selected 28 papers out of a total of 2340 from Scopus. Through backward snowballing, we identified 18 papers of interest out of a total of 114 publications. The other searching engines did not identify a sizeable number of new publications despite the large volume of papers screened: 7 out of 428 in IEEEXplore and 1 out of 261 in ACM DL. Generally, the selected studies account for books, journal publications, conference papers, dissertations, etc.

Out of the 54 selected primary studies, 26 are theoretical and 28 are empirical. Table 1 details the studies, identifying each publication with a code and its bibliographic reference. Both theoretical 


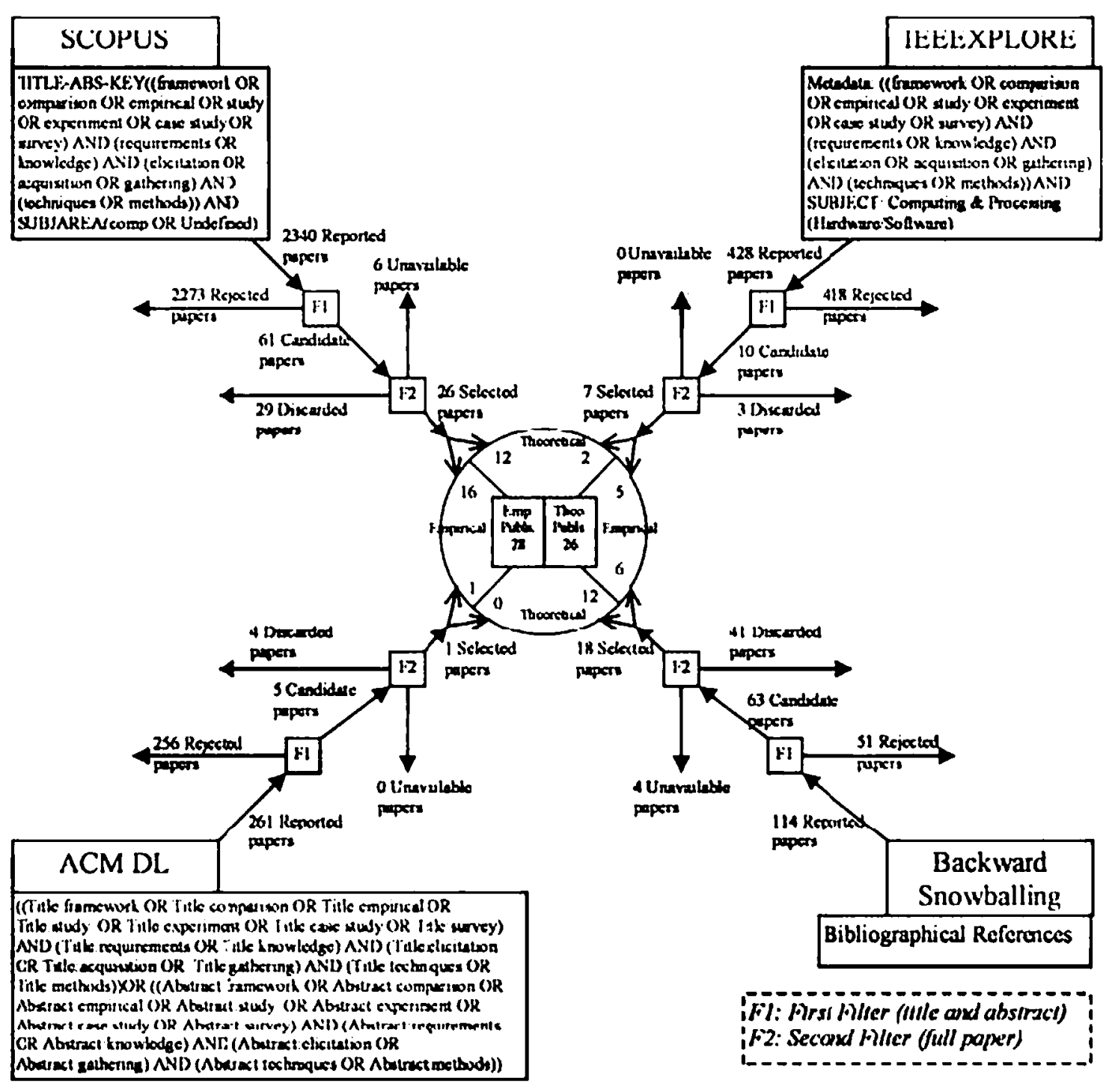

Fig. 2. Search method.

proposals and empirical studies are distributed equally across the search period. In other words, neither paper type seems to takes precedence over the other.

The publications are sourced from different areas: knowledge engineering (20: 8 theoretical, 12 empirical), software engineering (27: 16 theoretical, 11 empirical), information systems (5: 2 theoretical, 3 empirical), knowledge management ( 1 empirical) and product design ( 1 empirical).

Some publications represent a group of studies or proposals related (for example, Davis and Hickey [18] and Burton et al. [64]).

The extracted data are compiled in a table shown in Appendix.

\section{Results}

We aim to identify contextual attributes proposed to influence the effectiveness of the elicitation techniques, as well as to study the extent to which the influence of such attributes has been empirically confirmed. So, we first classified the contextual attributes proposed in theoretical works and studied in empirical studies (Section 5.1). Then we matched the theoretically defined attributes with empirically evaluated attributes (Section 5.2). Fi- nally, we studied which attributes have been empirically confirmed to influence elicitation technique effectiveness (Section 5.3).

\subsection{Attributes proposed in the literature}

This section addresses the response to research question RQ1: What contextual attributes have been proposed by theoretical research and/or empirically evaluated by empirical research as influencing the effectiveness of elicitation techniques?

We screened 54 primary studies and identified 127 contextual attributes that had been proposed or evaluated as having an influence (see Appendix). Some attributes were proposed in more than one paper. For example, articles T03, T26, T20, T24, T17, E06 and E15 propose Knowledge Types as impacting attribute. We grouped other attributes that were called differently but shared definition and were of the same type within the same category. Some degree of generalization was necessary to make the matching possible. For example, we clustered under Domain Familiarity (on the grounds of the similarity in their definition) Domain Knowledge and Experience in the Problem Domain (T19, T22) and Application Type (E08, T06). This reduction is based on the definitions of the attributes not on their names. For example, the generic attribute 
Table 1

Primary studies.

\begin{tabular}{|c|c|c|c|}
\hline Type & Code & Authors & Discipline \\
\hline \multirow[t]{26}{*}{ THEORETICAL } & T01 & Fazlollahi and Tanniru, 1991 [32] & \multirow[t]{16}{*}{ Software engineering } \\
\hline & T02 & Christel and Kang, 1992 [33] & \\
\hline & T03 & Maiden and Rugg, 1996 [17] & \\
\hline & T04 & Lauesen, $2002[34]$ & \\
\hline & T05 & Batista and Carvalho, 2003 [19] & \\
\hline & T06 & Davis and Hickey, 2003 [18] & \\
\hline & T07 & Tsumaki and Tamai, 2005 [35] & \\
\hline & T08 & Aranda et al., 2005 [36] & \\
\hline & T09 & Zowghi and Coulin, 2005 [13] & \\
\hline & $\mathrm{T} 10$ & Jiang and Eberlein, 2007 [24] & \\
\hline & T11 & Zhang, 2007 [37] & \\
\hline & $\mathrm{T} 12$ & Thew and Sutcliffe, 2008 [38] & \\
\hline & T13 & Proynova et al., 2010 [39] & \\
\hline & T14 & Kausar et al., $2010[40]$ & \\
\hline & T15 & Tiwari, Rathore and Gupta, 2012 [41] & \\
\hline & T16 & Serna, $2012[42]$ & \\
\hline & T17 & Kim and Courtney, 1988 [43] & \multirow[t]{8}{*}{ Knowledge engineering } \\
\hline & T18 & Byrd, Cossick and Zmud, 1992 [44] & \\
\hline & T19 & Dhaliwal and Benbazat, 1990 [45] & \\
\hline & $\mathrm{T} 20$ & Skidmore, 1994 [46] & \\
\hline & $\mathrm{T} 21$ & Moody, Blanton and Will, 1999 [29] & \\
\hline & $\mathrm{T} 22$ & Fowlkes et al., 2000 [31] & \\
\hline & $\mathrm{T} 23$ & Coulin, Zowghi and Sahraoui, 2006 [47] & \\
\hline & $\mathrm{T} 24$ & Hua, $2008[48]$ & \\
\hline & $\mathrm{T} 25$ & Davis et al., 2006 [49] & \multirow[t]{2}{*}{ Information systems } \\
\hline & $\mathrm{T} 26$ & Eva, $2001[50]$ & \\
\hline \multirow[t]{28}{*}{ EMPIRICAL } & E01 & Keil and Carmel, 1995 [51] & \multirow[t]{11}{*}{ Software engineering } \\
\hline & $\mathrm{E} 02$ & Moore and Shipman, 2000 [52] & \\
\hline & $\mathrm{E} 03$ & Damian and Zowghi, 2002 [53] & \\
\hline & E04 & Lloyd, Rosson, and Arthur, 2002 [54] & \\
\hline & E05 & Vale, Albuquerque and Beserra, 2011 [55] & \\
\hline & E06 & Boulila, Hoffmann and Herrmann, 2011 [56] & \\
\hline & $\mathrm{E} 07$ & Zapata et al., 2012 [57] & \\
\hline & E08 & Hadar, Soffer and Kenzi, 2012 [58] & \\
\hline & E09 & Ahmad, Tahir and Kasirun, 2012 [59] & \\
\hline & E10 & Niknafs and Berry, 2012 [60] & \\
\hline & E11 & Todoran, Seyff and Glinz, 2013 [61] & \\
\hline & E12 & Grabowski, 1988 [62] & \multirow[t]{12}{*}{ Knowledge engineering } \\
\hline & E13 & Crandall, 1989 [63] & \\
\hline & E14 & Burton et al., 1990 [64] & \\
\hline & E15 & McCloskey, Geiwitz and Kornell, 1991 [65] & \\
\hline & E16 & Massey and Wallace, 1991 [66] & \\
\hline & E17 & Rugg et al., 1992 [67] & \\
\hline & E18 & Corbridge et al., 1994 [68] & \\
\hline & E19 & Holsapple and Raj, 1994 [69] & \\
\hline & $\mathrm{E} 20$ & Chao and Salvendy, 1995 [70] & \\
\hline & $\mathrm{E} 21$ & Wagner, Chung and Najdawi, 2003 [71] & \\
\hline & $\mathrm{E} 22$ & Holsapple, Raj and Wagner, 2008 [72] & \\
\hline & E23 & Tan et al., $2010[73]$ & \\
\hline & $\mathrm{E} 24$ & Agarwal and Tanniru, 1990 [74] & \multirow[t]{3}{*}{ Information systems } \\
\hline & E25 & Browne and Rogich, 2001 [75] & \\
\hline & $\mathrm{E} 26$ & Scapolo and Miles, 2006 [76] & \\
\hline & $\mathrm{E} 27$ & Sauer, Schramme and Rüttinger, 2000 [77] & \multirow[t]{2}{*}{ Others } \\
\hline & E28 & Chiravuri, Nazareth, and Ramamurthy, 2011 [78] & \\
\hline
\end{tabular}

Problem Domain Categories identified in T18 looked like it might be associated with the Domain Types attribute. However, when we reviewed Byrd et al.'s paper, we found that the Problem Domain Categories referred to the classes of contextual information in the problem domain and not to specific application domains. Therefore, it was associated in the end with the Information Types attribute.

We grouped the 127 attributes proposed in the literature as 27 contextual attributes. The match between the attributes proposed in the primary studies and the 27 attributes that we identified can be seen in Appendix.

The 27 attributes are very diverse, but they are relatively easy to classify by their type or source for the purposes of categorization. Table 2 shows this classification and attribute clustering. We identified five factors or contextual attribute types [79]:
- Elicitor, member of the development team that elicits key information for requirements specification.

- Informant, person or persons from whom information is gathered.

- Problem domain, problem aspects that the software system under development is to address.

- Solution domain, aspects of software product being developed to address the problem.

- Elicitation process, aspects related to the management of the project as part of which the elicitation is conducted.

For example, Information Gathering Experience, Elicitation Technique Training, Domain Familiarity and Cognitive Aspects refer to the agent acting as the requirements engineer in the elicitation process, generically denoted as the Elicitor. 
Table 2

Classification of attributes by aspect.

\begin{tabular}{|c|c|}
\hline Aspect & Attribute \\
\hline Elicitor & $\begin{array}{l}\text { Information gathering experience } \\
\text { Elicitation technique training } \\
\text { Domain familiarity } \\
\text { Cognitive aspects }\end{array}$ \\
\hline Informant & $\begin{array}{l}\text { Number of informants } \\
\text { Stakeholder participation } \\
\text { Geographical aspects } \\
\text { Information source } \\
\text { Articulacy } \\
\text { Personal aspects }\end{array}$ \\
\hline Problem Domain & $\begin{array}{l}\text { Information types } \\
\text { Domain types } \\
\text { Uncertainty } \\
\text { Task types } \\
\text { Problem size } \\
\text { Complexity }\end{array}$ \\
\hline Solution Domain & $\begin{array}{l}\text { Product types } \\
\text { Criticality } \\
\text { Problem-solving methods }\end{array}$ \\
\hline Elicitation Process & $\begin{array}{l}\text { Purpose of requirements } \\
\text { Deliverable } \\
\text { Project environment } \\
\text { Elicitation project type } \\
\text { Communication type } \\
\text { Process constraints } \\
\text { Process time } \\
\text { Methodologies }\end{array}$ \\
\hline
\end{tabular}

5.2. Matching between attributes proposed in theory and evaluated in empirical studies

This section addresses the response to research question RQ2: Which theoretically proposed attributes have been empirically studied?

Researchers used different metrics to represent elicitation techniques effectiveness (for example, number of requirements, quality of requirements, productivity, etc.). Note that, irrespective of how effectiveness is represented, we aim to find out whether or not an attribute influences such elicitation technique effectiveness. This calls for some generalization of the elicitation technique effectiveness or performance construct.

The five aspects, according which we classified contextual attributes, have not received the same attention either theoretically or empirically. As shown in Fig. 3, Problem Domain is the aspect that has awoken most interest, and Solution Domain is the least researched aspect. Note that the focuses of theoretical and empirical papers match closely and are highly correlated $(r=0.97)$, that is, the aspects that are most researched in theory are also the empirically most studied issues. Therefore, theoretical and empirical interests in the contextual attributes that influence elicitation technique effectiveness are aligned at aspect levels.

We also found that experiments are the most common method (75\%) for empirically studying almost all aspects (with the sole exception of solution domain, where the number of case studies is greater). Note that the totals for both (theoretical and empirical) work types do not add up to the vertical sum because some publications deal with more than on attribute type.

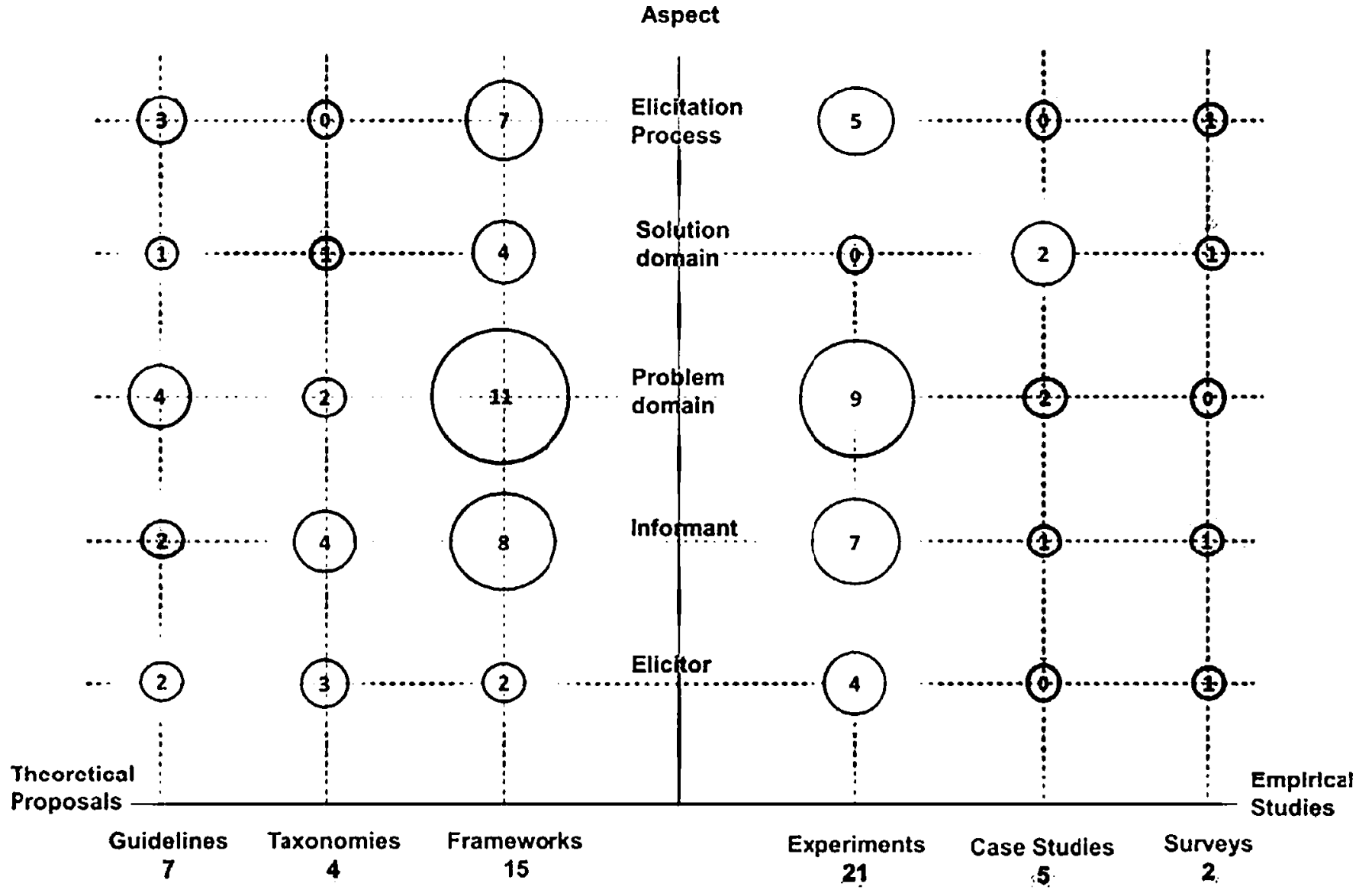

Fig. 3. Types of theoretical and empirical works by contextual aspect. 
Table 3

Matching between theory and empirics.

\begin{tabular}{|c|c|c|c|}
\hline Aspect & Attributes & Theoretical Works & Empirical Works \\
\hline Elicitor & $\begin{array}{l}\text { Information Gathering Ex- } \\
\text { perience } \\
\text { Elicitation Technique Train- } \\
\text { ing } \\
\text { Domain Familiarity } \\
\text { Cognitive Aspects }\end{array}$ & $\begin{array}{l}\text { T19 } \\
\text { T19, T06, T05 } \\
\text { T19, T22, T25, T06 } \\
\text { T05, T15, T06, T07 }\end{array}$ & $\begin{array}{l}\text { E04, E24 } \\
- \\
\text { E08(2), E10 } \\
\text { E05 }\end{array}$ \\
\hline Stakeholder & $\begin{array}{l}\text { Number of Informants } \\
\text { Stakeholder Participation } \\
\text { Geographical Aspects } \\
\text { Information Source } \\
\text { Articulacy } \\
\text { Personal Aspects }\end{array}$ & $\begin{array}{l}\text { T03, T14, T06 } \\
\text { T07, T14, T05 } \\
\text { T06(2), T11 } \\
\text { T19, T16, T15(2) } \\
\text { T25 } \\
\text { T19(2), T12(3), T13, T11, T18, T08, }\end{array}$ & $\begin{array}{l}E 16 \\
E 04 \\
E 03(2), E 04 \\
E 14, E 11 \\
E 13 \\
E 18, E 20, E 23, E 28\end{array}$ \\
\hline $\begin{array}{l}\text { Problem Do- } \\
\text { main }\end{array}$ & $\begin{array}{l}\text { Information Types } \\
\text { Domain Types } \\
\text { Uncertainty } \\
\text { Task Types } \\
\text { Problem Size } \\
\text { Complexity }\end{array}$ & $\begin{array}{l}\text { T03(3), T04, T26, T18, T20, T24, T21, } \\
\text { T11, T17 } \\
\text { T23, T07 } \\
\text { T19, T06, T25, T16, T11, T17, T01, } \\
\text { T19 } \\
\text { T17, T10, T07 } \\
\text { T17, T10, T06 }\end{array}$ & $\begin{array}{l}\text { E25, E26, E12, E15, } \\
\text { E02, E06 } \\
\text { E14 } \\
- \\
\text { E21, E16 } \\
- \\
E 22, E 19\end{array}$ \\
\hline $\begin{array}{l}\text { Solution Do- } \\
\text { main }\end{array}$ & $\begin{array}{l}\text { Product Types } \\
\text { Criticality } \\
\text { Problem-Solving Methods }\end{array}$ & $\begin{array}{l}\text { T10, T06, T15(2), T14(3) } \\
\text { T10 } \\
\text { T21, T19 }\end{array}$ & $\begin{array}{l}\text { E01, E11 } \\
- \\
-\end{array}$ \\
\hline $\begin{array}{l}\text { Elicitation } \\
\text { Process }\end{array}$ & $\begin{array}{l}\text { Purpose of Requirements } \\
\text { Deliverable } \\
\text { Project Environment } \\
\text { Elicitation Project Type } \\
\text { Communication Type } \\
\text { Process Constraints } \\
\text { Process Time } \\
\text { Methodologies }\end{array}$ & $\begin{array}{l}\text { T03, T16 } \\
\text { T23 } \\
\text { T15 } \\
\text { T23 } \\
\text { T03, T14(3), T16, T10(2) } \\
\text { T09, T22, T02 } \\
\text { T15, T19 }\end{array}$ & $\begin{array}{l}- \\
- \\
- \\
\text { E07 } \\
\text { E18, E17, E09, E27, E11 } \\
\text { E11 } \\
- \\
-\end{array}$ \\
\hline
\end{tabular}

With respect to the individual attributes, Table 3 shows the number of theoretical and empirical works covering each of the 27 generic attributes. There exist three scenarios: attributes are studied in both theoretical and empirical works (white cells); attributes are studied only in theoretical papers (light grey cells), and attributes are investigated only in empirical studies (dark grey cells). There is a moderate positive correlation between the number of theoretical and empirical papers per attribute $(r=0.5)$.

Fig. 4 shows the attribute distribution by theoretical/empirical coverage. Both theoretical and empirical works were found for 16 out of the 27 generic attributes (59.3\%). There are more often more theoretical papers proposing than empirical papers studying an attribute (11 out of 16 cases). The attention that some attributes received differs by study type. For example, Information Types is the most researched attribute, appearing in nine theoretical proposals and six empirical studies. On the other hand, Task Types is investigated in only two empirical studies and one theoretical work.

10 out of the 27 generic attributes (37\%) are proposed in theoretical works but have not yet been studied empirically. Uncertainty and Process Constraints attributes are a case in point; they appear in seven theoretical works but are not subject of any empirical study. Finally, only one attribute, Communication Type, appeared in empirical studies but has not been addressed in theoretical works (3.7\%).

\subsection{Match between theoretical and empirical results}

This section addresses the response to research question RQ3: Which theoretically proposed attributes have been empirically confirmed as having an influence on the effectiveness of elicitation techniques?

In order to learn whether the influence of an attributes on the effectiveness of elicitation techniques is confirmed, we studied the match between theoretical proposals and empirical results for each contextual attribute. In other words, we compared the proposals of the theoretical literature against the results of empirical studies that investigate the same attribute than the proposals.

For the purposes of theoretical/empirical verification, we need to decide whether or not an empirical study provides support for the influence of a contextual attribute. To do so, we classified the conclusions of the empirical studies into two types:

- in favour of the influence (FI) of an attribute, that is, evidence is found that the attribute influences the effectiveness of elicitation techniques, or

- against the influence (AI), that is, no evidence is found that an attributes have an influence.

For example, looking at the Domain Familiarity attribute, E08 were able to reject the hypothesis that "There is no difference between analysts with and without domain knowledge in terms of the amount of specific questions in an interview" because they found the difference to be a statistically significant $(p=0.01)$. In 


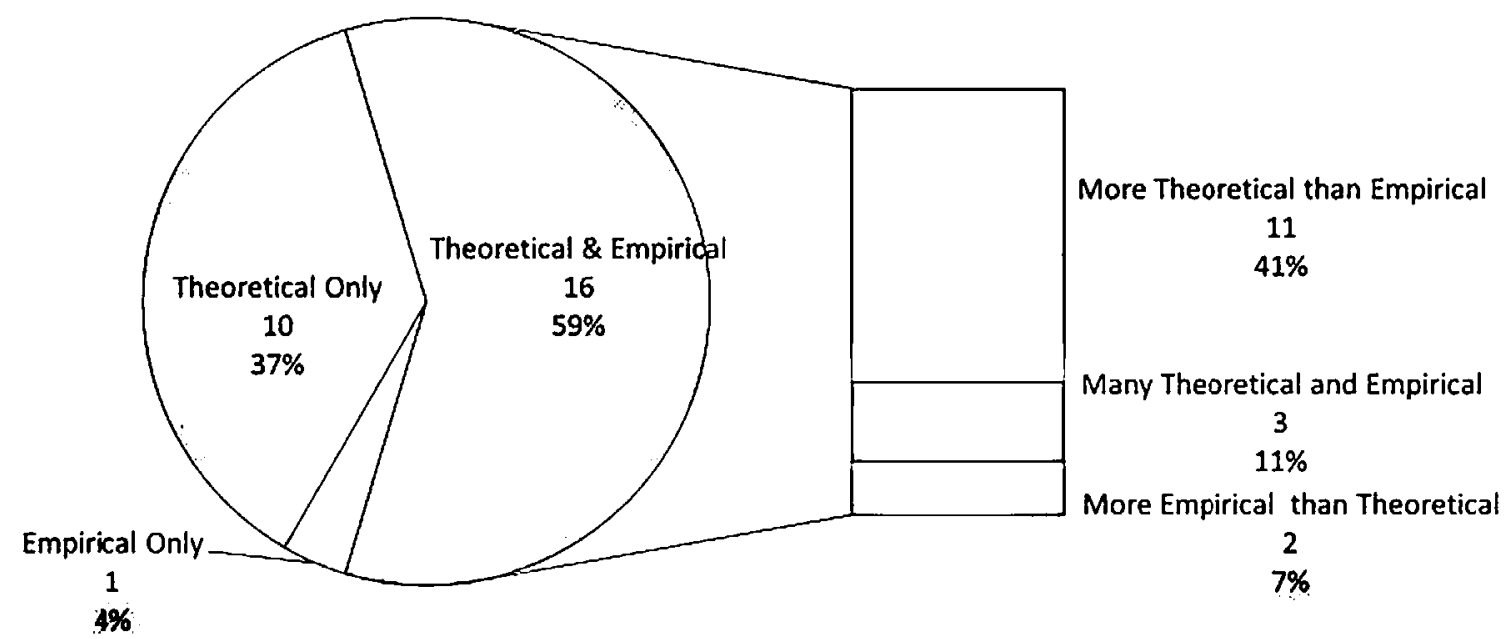

Fig. 4. Distribution of attributes by theoretical/empirical coverage.

Table 4

Match between contextual attributes and empirical study results.

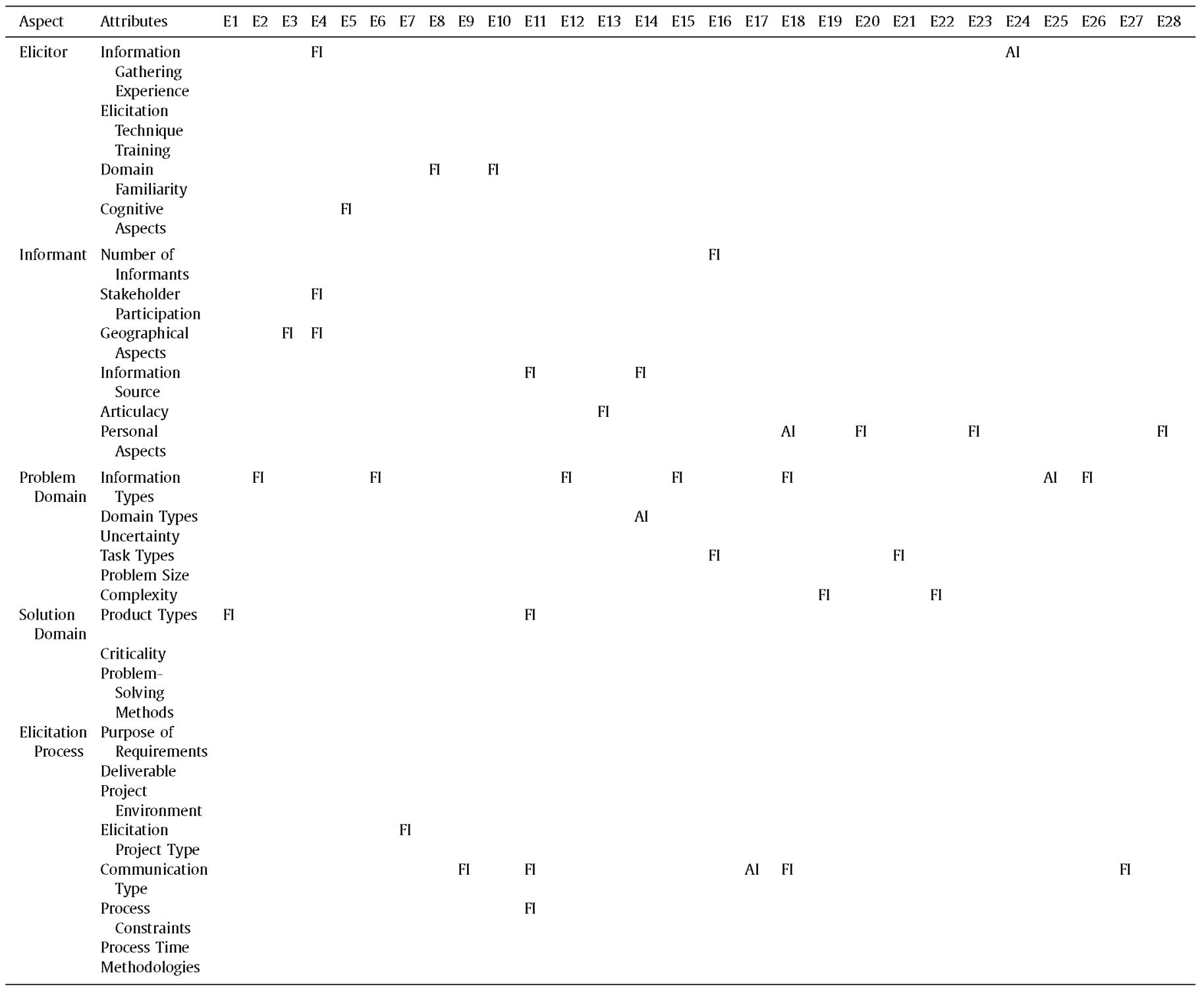




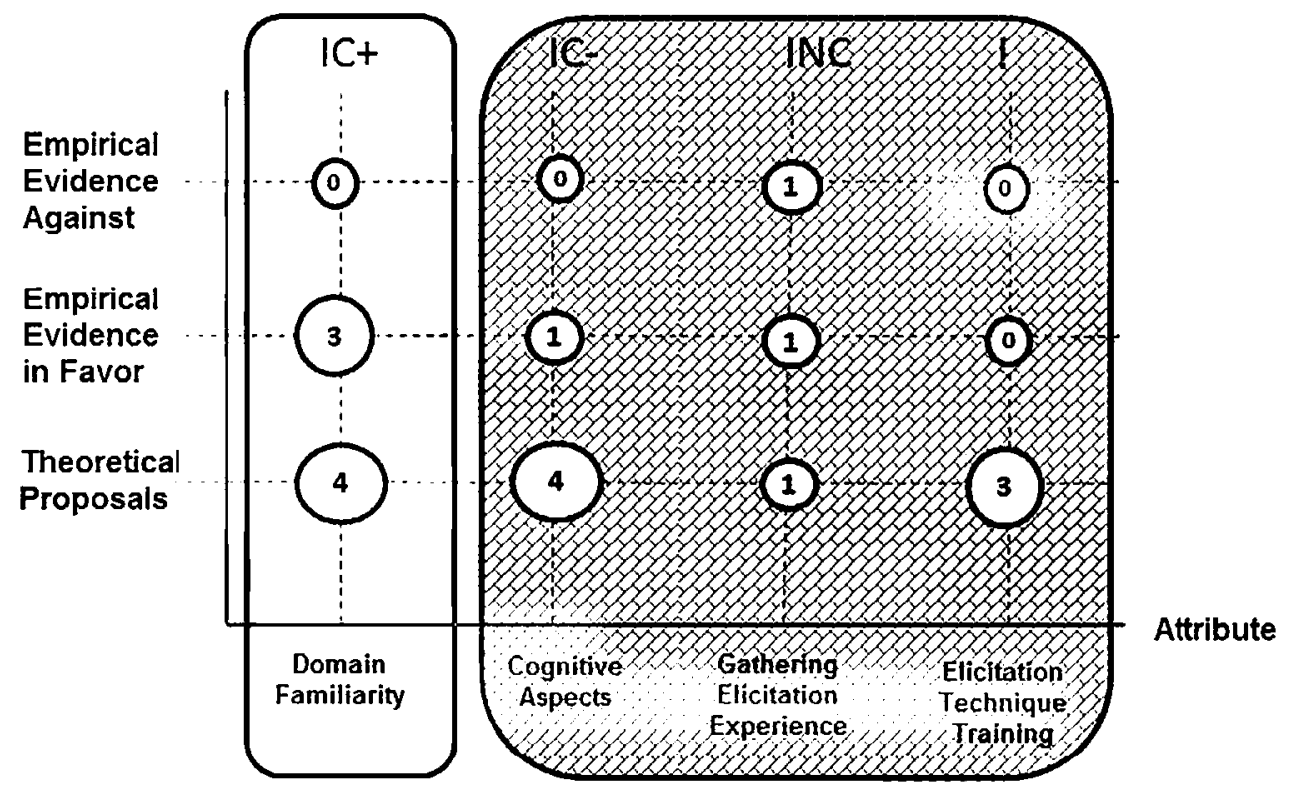

Fig. 5. Results for the Elicitor aspect.

Table 5

Designed synthesis procedure.

\begin{tabular}{|c|c|c|}
\hline Code & Dictum & Description \\
\hline IC+ & Strong confirmation of influence & $\begin{array}{l}2 \text { or more pieces of FI than AI } \\
\text { evidence }\end{array}$ \\
\hline IC- & Weak confirmation of influence & $\begin{array}{l}1 \text { more piece of FI than } \mathrm{AI} \\
\text { evidence }\end{array}$ \\
\hline INC & Influence is not confirmed & $\begin{array}{l}\text { Equal or greater number of } \mathrm{AI} \\
\text { than FI results }\end{array}$ \\
\hline$!$ & Influence is not confirmed & There are no empirical studies \\
\hline
\end{tabular}

this case, the study provides evidence in favour of the influence of the Domain Familiarity attribute on the effectiveness of the interview technique.

In another case, E17 compared the Information Types elicited using different types of sorting techniques and did not find a statistically significant difference between techniques. Therefore, the influence of the Information Types attribute is not confirmed. Consequently, this empirical study is considered to provide a result that is against the influence of the Information Types attribute on the effectiveness of sorting techniques. Table 4 shows which empirical studies are in favour of or against the influence of a particular contextual attribute.

Predictably, empirical studies are not necessarily consistent with each other: some studies may be in favour of and others against the influence of one and the same attribute (e.g., E7 and E9 for Personal Aspects). On this ground, we need to establish some sort of aggregation procedure in order to determine whether or not each attribute really influences the effectiveness of elicitation techniques. The primary studies do not meet the requirements for quantitative aggregation (e.g., a meta-analysis). Therefore, we have no choice but to use less sophisticated procedures such as vote counting, which has been used for synthesis in the past [15]. Vote counting has the drawback of overestimating the negative influence of studies with low statistical power, which are very common in software engineering [80]. However, this drawback may be an advantage in this research, as the conclusions reached through vote counting tend to be conservative.

Table 5 illustrates the synthesis procedure that we use. We consider that there is strong confirmation of the influence of an at- tribute when there are at least two more results of empirical studies that are in favour of than against the influence. Likewise, we consider that there is weak confirmation of the influence of an attribute when there is one more result in favour of than against the influence. Finally, we consider that the influence of an attribute is not confirmed when there is an equal or greater number of results against than in favour of the influence.

Although stated in quantitative terms in Table 5 , the synthesis procedure we followed actually emulates the reasoning of a human decision maker based on the information provided by primary studies.

For example, there are authors who suggest in their theoretical proposals that Elicitor Domain Familiarity is an influential attribute. For example,

- T19 state that "This attribute can be hypothesised to have a potential impact on the process of knowledge acquisition";

- T22 who suggest that "Interviews may require extensive domain knowledge" in their comparison of techniques;

- T25 claim that "Some technique allows analysts to elicit requirements in scenarios where they do not have business knowledge"; and

- T06 consider this attribute in their ontology, as "The match between the characteristics of the bridge-builders and the elicitation techniques used is essential".

On the other hand, we have empirical studies investigating this attribute:

- Empirical studies by E08 found significant confirmation that:

- "Analysts who had domain knowledge posed more specific questions"

- "Domain knowledge supports the communication between the analyst and the stakeholders"

- "Domain knowledge can positively as well as negatively affect the formation of the analyst's deep understanding of the customer's needs".

- E10 also found evidence that "The mix of domain familiarities in a team affects the quality of the ideas generated by the team". 


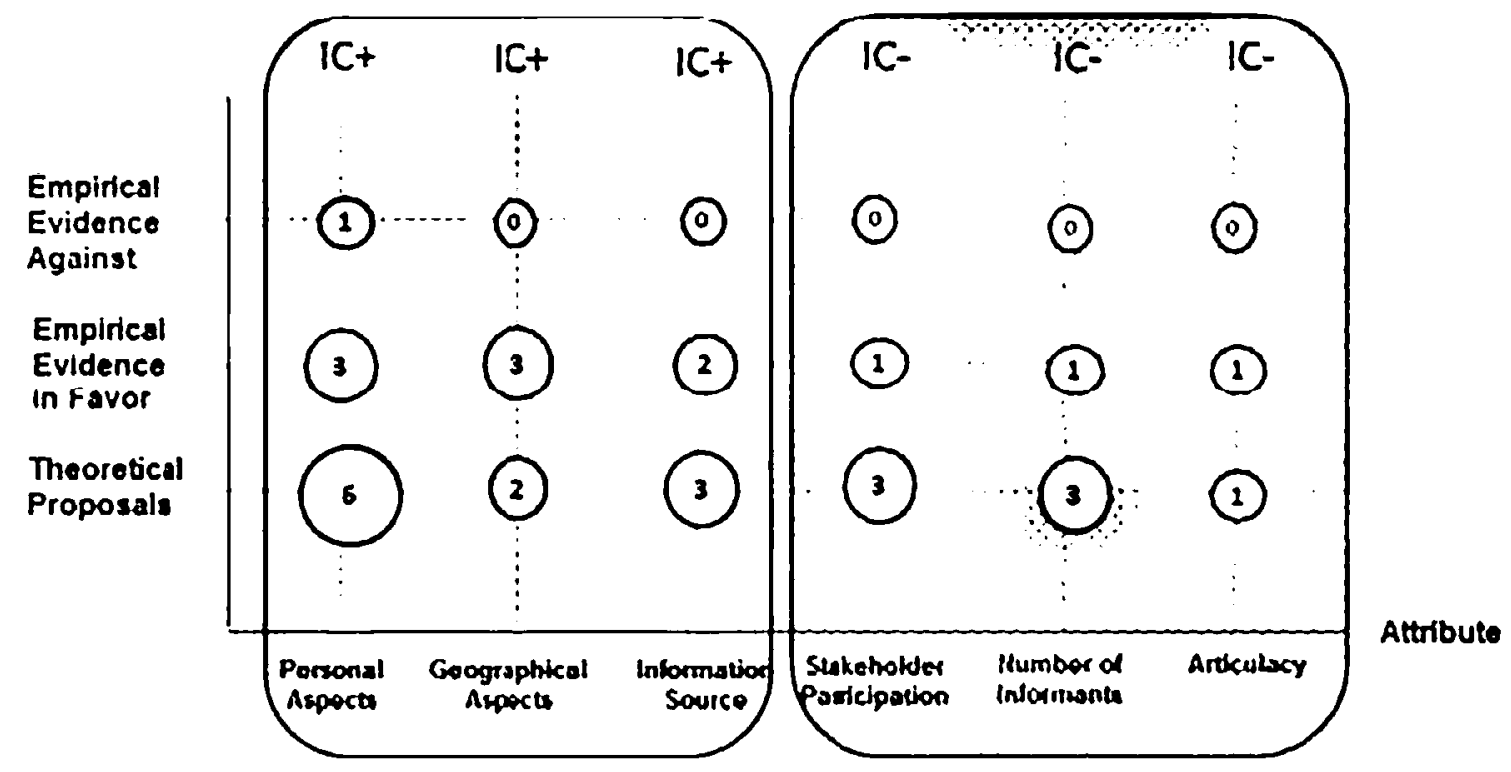

Fig. 6. Results for the Informant aspect.

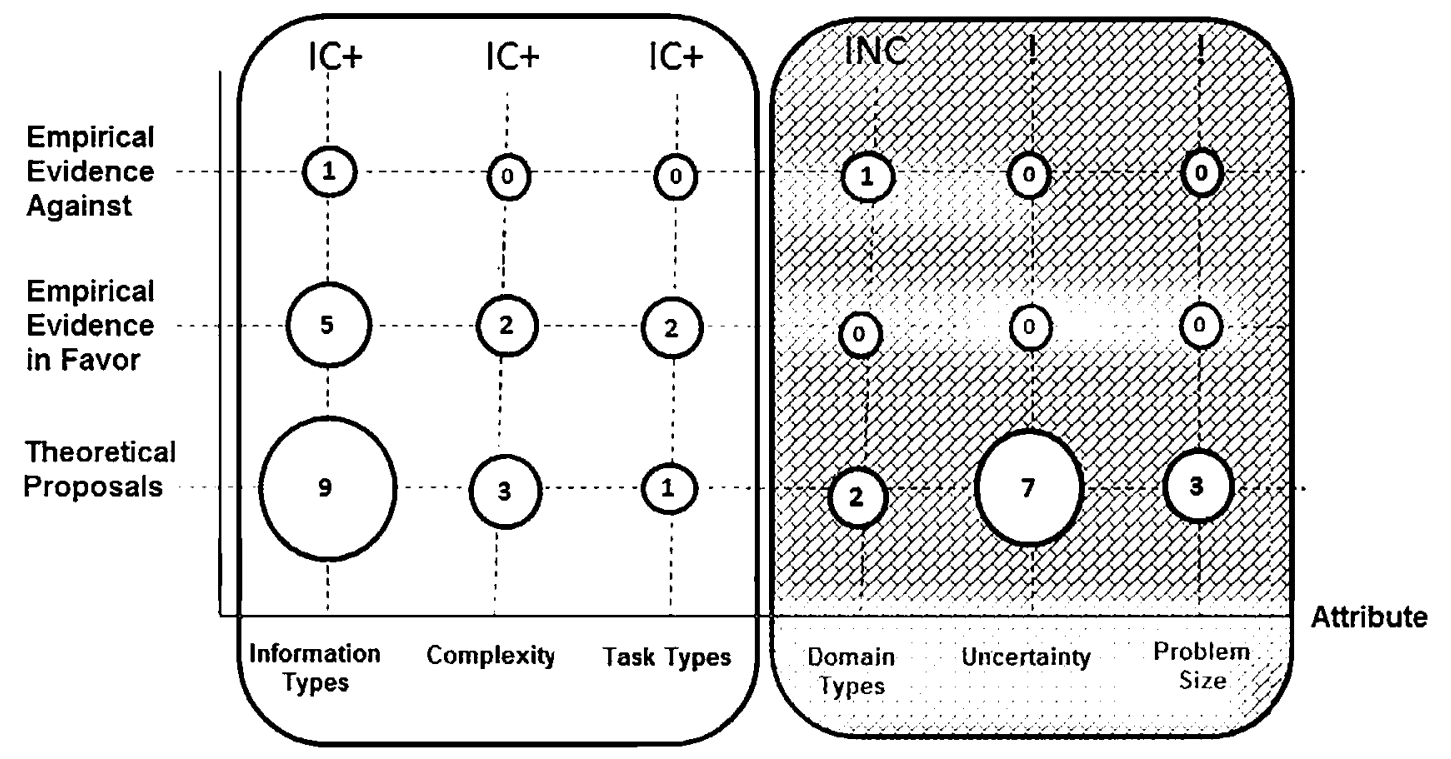

Fig. 7. Results for the problem domain aspect.

This favourable empirical evidence strongly confirmed the influence of the Elicitor Domain Familiarity on the effectiveness of elicitation techniques (IC+).

We applied such synthesis procedure to all attributes. Figs. 59 below show the match between theory and experience that we get after synthesizing empirical results. The attributes shaded light grey represent attributes that are well accounted for in empirical studies, and attributes filled pattern represent attributes that require further empirical research.

As Fig. 5 shows, the influence of two out of the four Elicitor attributes was confirmed: Cognitive Aspects and Domain Familiarity. For another attribute, Information Gathering Experience, the influence was not confirmed. Finally, no empirical studies were found for the Elicitation Technique Training attribute.

With respect to informants, six attributes have been proposed. As shown in Fig. 6, there is at least one empirical study for all attributes, and they were all confirmed to have an influence. Evidence for three was weak: Number of Informants, Stakeholder Participation and Articulacy. The influence of the other three - Geographical Aspects, Information Source and Personal Aspects - was strongly confirmed.

Problem Domain aspect is composed of six attributes, as shown in Fig. 7. In this case, its influence was strongly confirmed for three: Information Types, Task Types and Complexity. We found evidence against the influence of Domain Types, and no empirical studies were found for the other two attributes: Uncertainty and Problem Size. More empirical research is required for the last three attributes.

Solution Domain is composed of three attributes. As shown in Fig. 8, only one was confirmed as having an influence: Product Types. No empirical studies were found for the other two at- 


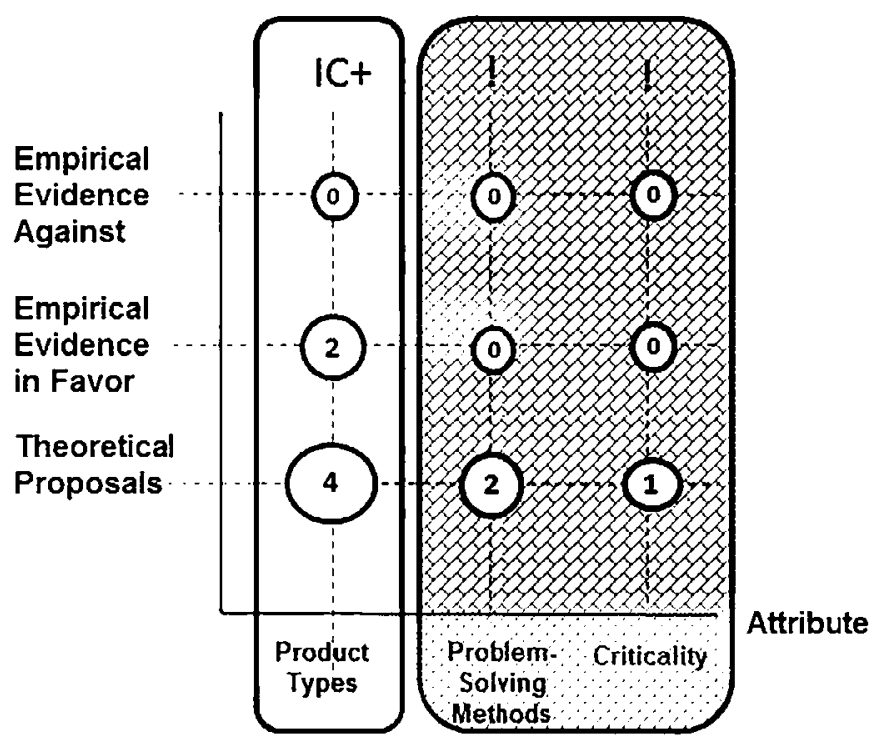

Fig. 8. Results for the solution domain aspect.

tributes: Criticality and Problem-Solving Methods. In other words, more empirical research is required for the last two attributes.

Finally, the Elicitation Process aspect has eight attributes. Only three were confirmed as having an influence: Type of Elicitation Project, Process Constraints and Communication Type. Note that Communication Type was the only attribute that did not appear in theoretical proposals. However, it was, as shown in Fig. 9, the empirically most studied attribute of this aspect. No related empirical studies were found for the other five attributes, which means that this is the elicitation aspect in greatest need of empirical research.

Summarizing, and as shown in Fig. 10:

- The influence of nine out of 27 contextual attributes (33\%) was confirmed (IC+): Domain Familiarity, Geographical Aspects, Information Source, Personal Aspects, Information Types, Task Types, Complexity, Product Types and Communication Type.

- Six out of the 27 attributes (22\%) were weakly confirmed (IC-): Cognitive Aspects, Number of Informants, Stakeholder Partici- pation, Articulacy, Type of Elicitation Project and Process Constraints.

- There was not enough evidence of two out of the 27 attributes having an influence (8\%) (INC): Information Gathering Experience and Domain Types.

Briefly, about half of the theoretically proposed attributes have been empirically confirmed as having an influence on the effectiveness of requirements elicitation techniques.

\subsection{Result for theoretical-empirical alignment}

Finally, this section addresses the response to research question RQ4: Has this topic been sufficiently empirically researched?

The results are summarised in Table 6 which classifies the empirical evidence in favour and against according to the type of empirical method used (EX: experiments; CS: Case studies; SU: Surveys).

Remember that, in some cases, there are more attributes than theoretical papers or more evidence than empirical studies because the respective papers proposed more than one version of the same attribute or gathered more than one piece of evidence with respect to its influence, respectively.

We can summarise the results with respect to their alignment between theory and empirics in Table 7 . The coverage between theory and empirical investigation is good for attributes that are strongly confirmed $(\sqrt{ } \sqrt{ })$ (good alignment) while weak confirmation $(\sqrt{ })$, no confirmation $(x)$, or lack of empirical studies (!) mean that more empirical research is required (poor alignment).

\section{Discussion of findings}

With respect to the research of attributes that influence the effectiveness of elicitation techniques we can state that there is some level of coordination between empirical research and theoretical proposals. In other words, the empirical researchers tend to study (with one exception) attributes proposed by theoreticians (whether consciously or otherwise). We even found a moderate correlation between how much attention both theoretical proposals and empirical research pay to every contextual attribute, which is unchanging over time.

Note that this research did not set out to corroborate the influence with respect to each particular technique since there are

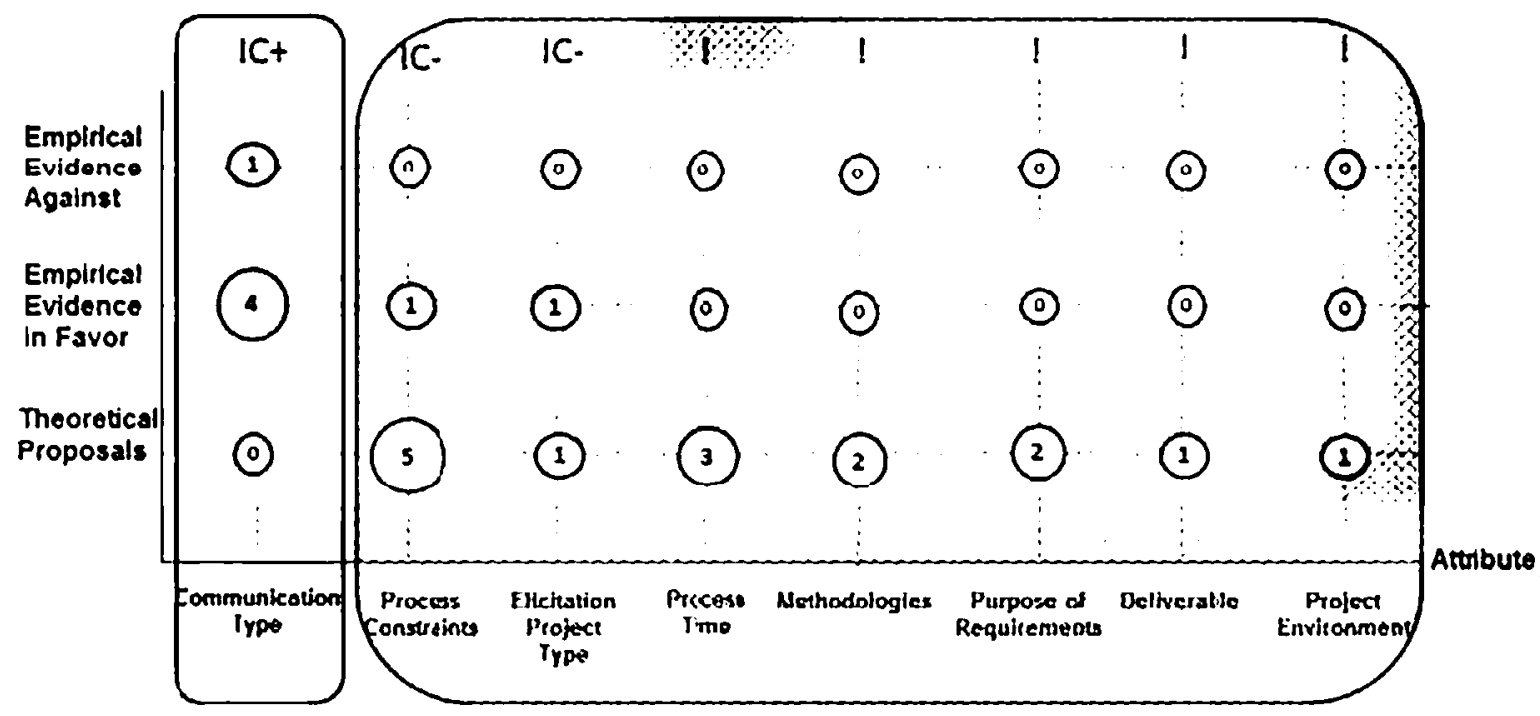

Fig. 9. Results for the elicitation process aspect. 
Altributes not

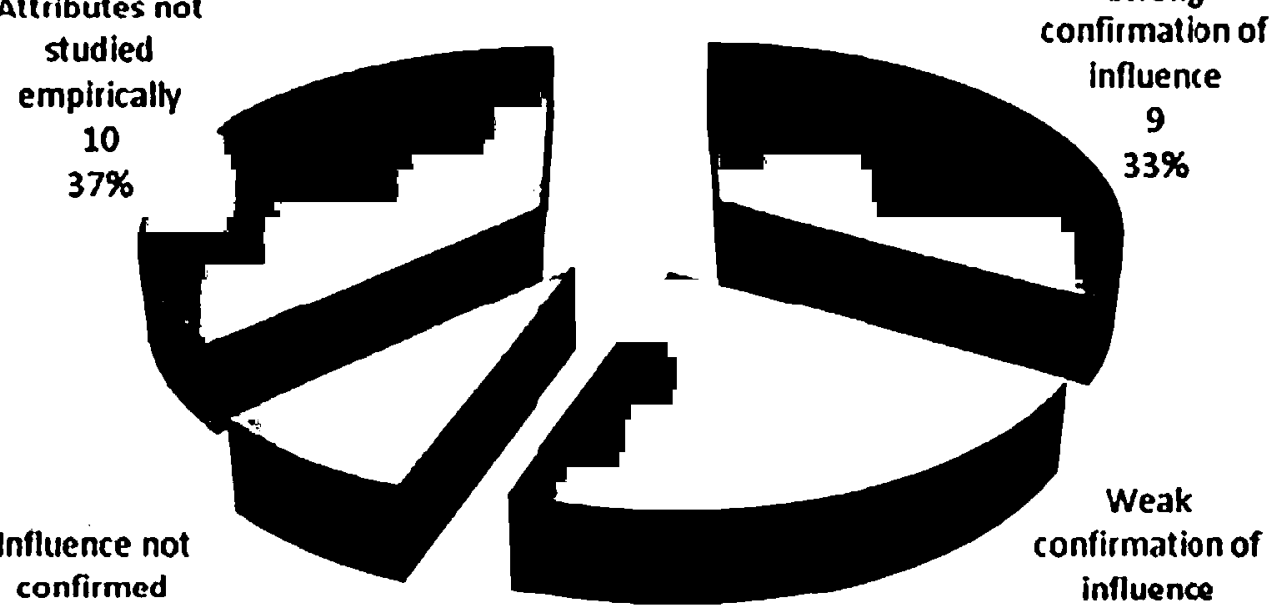

2

6

$8 \%$

$22 \%$

Fig. 10. Breakdown of the results.

Table 6

Match between theoretical and empirical works.

\begin{tabular}{|c|c|c|c|c|c|c|c|c|c|c|c|c|c|}
\hline \multirow{3}{*}{ Aspect } & \multirow{3}{*}{$\begin{array}{c}\text { Generic } \\
\text { Attributes }\end{array}$} & \multirow{2}{*}{\multicolumn{2}{|c|}{$\begin{array}{l}\text { Theoretical } \\
\text { proposals } \\
\text { (Number) }\end{array}$}} & \multicolumn{9}{|c|}{ Empirical Studies (Number) } & \multirow{3}{*}{ Dictum } \\
\hline & & & & \multirow{2}{*}{$\begin{array}{l}\text { Total } \\
\text { Papers }\end{array}$} & \multicolumn{4}{|c|}{ FI Evidence } & \multicolumn{4}{|c|}{ AI Evidence } & \\
\hline & & Papers & Aftributes & & Total & $\mathbf{E X}$ & cs & SU & Total & $\mathbf{E X}$ & Cs & SU & \\
\hline \multirow{3}{*}{ Elicitor } & $\begin{array}{l}\text { Information } \\
\text { Gathering } \\
\text { Experience }\end{array}$ & 1 & 1 & 2 & 1 & 1 & 0 & 0 & 1 & 1 & 0 & 0 & INC \\
\hline & $\begin{array}{l}\text { Domain Famil- } \\
\text { jarity }\end{array}$ & 4 & 4 & 2 & 3 & 3 & 0 & 0 & 0 & 0 & 0 & 0 & IC+ \\
\hline & $\begin{array}{l}\text { Cognitive } \\
\text { Aspects }\end{array}$ & 4 & 4 & 1 & 1 & 0 & 0 & 1 & $\mathbf{0}$ & 0 & 0 & 0 & IC- \\
\hline \multirow{6}{*}{ Stakeholder } & $\begin{array}{l}\text { Number of } \\
\text { Informants }\end{array}$ & 3 & 3 & 1 & 1 & 1 & 0 & 0 & $\mathbf{0}$ & 0 & 0 & 0 & IC- \\
\hline & $\begin{array}{l}\text { Stakeholder } \\
\text { Participation }\end{array}$ & 3 & 3 & 1 & 1 & 1 & 0 & 0 & 0 & 0 & 0 & 0 & IC- \\
\hline & $\begin{array}{l}\text { Geographical } \\
\text { Aspects }\end{array}$ & 2 & 3 & 2 & 3 & 1 & 2 & 0 & 0 & 0 & 0 & 0 & IC+ \\
\hline & $\begin{array}{l}\text { Information } \\
\text { Source }\end{array}$ & 3 & 4 & 2 & 2 & 1 & 0 & 1 & 0 & 0 & 0 & 0 & IC+ \\
\hline & Articulacy & 1 & 1 & 1 & 1 & 1 & 0 & 0 & 0 & 0 & 0 & 0 & IC- \\
\hline & $\begin{array}{l}\text { Personal As- } \\
\text { pects }\end{array}$ & 6 & 9 & 4 & 3 & 2 & 1 & 0 & 1 & 1 & 0 & 0 & IC+ \\
\hline \multirow{4}{*}{$\begin{array}{l}\text { Problem } \\
\text { Domain }\end{array}$} & $\begin{array}{l}\text { Information } \\
\text { Types }\end{array}$ & 9 & 11 & 6 & 5 & 4 & 1 & 0 & 1 & 1 & 0 & 0 & IC+ \\
\hline & Domain Types & 2 & 2 & 1 & 0 & 0 & 0 & 0 & 1 & 1 & 0 & 0 & INC \\
\hline & Task Types & 1 & 1 & 2 & 2 & 1 & 1 & 0 & 0 & 0 & 0 & 0 & IC+ \\
\hline & Complexity & 3 & 3 & 2 & 2 & 2 & 0 & 0 & 0 & 0 & 0 & 0 & IC+ \\
\hline $\begin{array}{l}\text { Solution } \\
\text { Domain }\end{array}$ & Product Types & 4 & 7 & 2 & 2 & 0 & 1 & 1 & 0 & 0 & 0 & 0 & IC+ \\
\hline \multirow{3}{*}{$\begin{array}{l}\text { Elicitation } \\
\text { Process }\end{array}$} & $\begin{array}{l}\text { Type of Elicita- } \\
\text { tion Project }\end{array}$ & 1 & 1 & 1 & 1 & 1 & 0 & 0 & 0 & 0 & 0 & 0 & IC- \\
\hline & $\begin{array}{l}\text { Communication } \\
\text { Type }\end{array}$ & 0 & 0 & 5 & 4 & 3 & 0 & 1 & 1 & 1 & 0 & 0 & IC+ \\
\hline & $\begin{array}{l}\text { Process Con- } \\
\text { straints }\end{array}$ & 5 & 7 & 1 & 1 & 0 & 0 & 1 & 0 & 0 & 0 & 0 & IC- \\
\hline
\end{tabular}


Table 7

Alignment between theoretical and empirical works.

\begin{tabular}{|c|c|c|c|}
\hline Aspect & Generic Attributes & Findings & Alignment \\
\hline Elicitor & $\begin{array}{l}\text { Information Gathering Experience } \\
\text { Elicitation Techniques Training } \\
\text { Domain Familiarity } \\
\text { Cognitive Aspects }\end{array}$ & $\begin{array}{l}x \\
! \\
v \sqrt{ } \\
v\end{array}$ & $\begin{array}{l}\text { Poor } \\
\text { Poor } \\
\text { Good } \\
\text { Poor }\end{array}$ \\
\hline Stakeholder & $\begin{array}{l}\text { Number of Informants } \\
\text { Stakeholder Participation } \\
\text { Geographical Aspects } \\
\text { Information Source } \\
\text { Articulacy } \\
\text { Personal Aspects }\end{array}$ & $\begin{array}{l}v \\
v \\
v V \\
v V \\
v \\
v v\end{array}$ & $\begin{array}{l}\text { Poor } \\
\text { Poor } \\
\text { Good } \\
\text { Good } \\
\text { Poor } \\
\text { Good }\end{array}$ \\
\hline Problem Domain & $\begin{array}{l}\text { Information Types } \\
\text { Domain Types } \\
\text { Uncertainty } \\
\text { Task Types } \\
\text { Problem Size } \\
\text { Complexity }\end{array}$ & $\begin{array}{l}\mathrm{V} v \\
\times \\
! \\
\mathrm{v} v \\
! \\
\mathrm{v} v\end{array}$ & $\begin{array}{l}\text { Good } \\
\text { Poor } \\
\text { Poor } \\
\text { Good } \\
\text { Poor } \\
\text { Good }\end{array}$ \\
\hline Solution Domain & $\begin{array}{l}\text { Product Types } \\
\text { Criticality } \\
\text { Problem-Solving Methods }\end{array}$ & $\begin{array}{l}\sqrt{ } \mathrm{V} \\
! \\
!\end{array}$ & $\begin{array}{l}\text { Good } \\
\text { Poor } \\
\text { Poor }\end{array}$ \\
\hline Elicitation Process & $\begin{array}{l}\text { Purpose of Requirements } \\
\text { Deliverable } \\
\text { Project Environment } \\
\text { Elicitation Project Type } \\
\text { Communication Type } \\
\text { Process Constraints } \\
\text { Process Time } \\
\text { Methodologies }\end{array}$ & $\begin{array}{l}\text { ! } \\
! \\
! \\
\sqrt{ } \\
\sqrt{ } \mathrm{V} \\
\sqrt{ } \\
! \\
!\end{array}$ & $\begin{array}{l}\text { Poor } \\
\text { Poor } \\
\text { Poor } \\
\text { Poor } \\
\text { Good } \\
\text { Poor } \\
\text { Poor } \\
\text { Poor }\end{array}$ \\
\hline
\end{tabular}

not enough empirical studies at the technique level to do so. If, for a technique, an empirical study gathered evidence that different attribute values led to different technique effectiveness effects or two techniques were observed to have different effectiveness values for the same attribute value, then the hypothesis that the attribute influences the effectiveness of the elicitation techniques was accepted.

The results show that the influence of 15 out of 27 attributes was to some extent confirmed (55\%), whereas we were unable to confirm the influence of two attributes $(8 \%)$. So, the theoretical proposals were generally well founded. Only two theoretically proposed attributes have been empirically confirmed not to have an influence.

Note that the attribute values played a role in determining their influence. Attribute values were generally categorical. In some cases, they were nominal (non-hierarchical), and, in other cases, ordinal (values with an order, sequence or natural progression). Ordinal values might include a zero value for the attribute somehow representing that the attribute is non-existent (for example, no experience or no domain familiarity). The influence could be confirmed if there was an effectiveness difference between one or more techniques for different attribute values, irrespective of the direction of the effectiveness improvement. In other words, some techniques might perform better for zero attribute values, whereas others might yield better results for values other than zero. Alternatively, technique effectiveness for some attributes could upgrade or degrade the higher the respective values are in the hierarchy (or degrade or upgrade as the attribute values decrease).
We concluded that the amount of empirical research addressing which attributes influence the effectiveness of elicitation techniques is insufficient:

- Of the theoretically proposed attributes, 37\% have not attracted any empirical research whatsoever.

- Of the proposed attributes, $26 \%$ were addressed only by one empirical study.

- Further empirical research is required for two-thirds (67\%) of the attributes.

\section{Limitations of the study}

The mapping study that we have carried out aims to identify as much available information as possible in order to answer the research questions. However, even though we tried to cover as many publications as possible considering a broad search string, we are likely to have missed some, primarily empirical, works. There are several publications or scientific events that deal with empirical software engineering issues (e.g., Workshop on Requirements Engineering - WER - and Workshop Experimental Software Engineering Latin American Workshop - ESELAW -), which are not systematically indexed in the major databases taken into account in this study: Scopus, IEEE Xplore and ACM DL. To address this issue, we reviewed some of these scientific events manually. We also reviewed books and $\mathrm{PhD}$ theses in order to identify more primary studies.

A key aspect that may influence the results is related to the reduction and simplification of the contextual attributes defined in 
the primary studies. As specified in Section 5.1, it was necessary to clean up the 127 attributes proposed in the literature by matching equivalent attributes. The result was a reduction of the number of attributes from 127 to 27 . The 27 attributes of the study represent attributes that are very similar but with slight different names. There exist the threat that we might have misunderstood or made mistakes in the linkage we have done. However, we are quite confident in the coupling since names where mostly clear and meaningful and differences were mainly synonym terms. Besides decisions were discussed and agreed by the three authors, but we cannot rule out decision making being biased, though we expect not to.

Other threat of our study is that we obtain evidence at type of attribute level, rather than at attribute level as we would wish. Unfortunately very often there is only one study for every attribute so we can only get enough evidence if we generalize attributes: take into account evidence not for a specific attribute, but evidence from several studies of a type of attribute. Generalization of attributes to type of attributes is the strategy we have applied to overcome the small number of studies.

Another limitation of this study is the problem of associating a level of reliability with types of empirical methods. It is hard to determine how well empirically confirmed an attribute when empirical studies of different types yield contradictory results; for example, a survey with evidence in favour and an experiment with evidence against. Fortunately, whenever there was evidence against, the source was always an experiment (in fact, as Table 6 shows, there was no evidence against from case studies or surveys), and there were experiments in favour that we could use for comparison, and therefore there was never any question as to which decision to make.

Notice that to assess the reliability of each empirical study, a detailed analysis is required of how the method was applied in each case, of the philosophical stance adopted as empirical truth by the authors and, generally, of how validity threats are addressed. The evaluation of the quality of the empirical studies is beyond the scope of this research.

Likewise, the major decision with respect to the dictum for each attribute was whether or not the influence of the contextual attributes was confirmed. It is questionable whether a single piece of evidence in favour can confirm the influence of the respective attribute. Since our aim is to discover the alignment between what has been proposed theoretically and what has been studied empirically, it was more important to identify any attributes that did not have associated empirical studies or for which the evidence in favour did not outweigh evidence against.

Finally, remember that the shortage of empirical studies dealing with the same attribute and the same technique led us to abandon the idea of making a more fine-grained comparison of the influence at technique level.

\section{Conclusion}

This paper reports a systematic mapping study on the contextual attributes influencing the effectiveness of requirements elicitation techniques. In particular, this mapping reviewed the theoretical and empirical publications to determine how aligned theoretical papers proposing contextual attributes are with empirical studies using these attributes.

The results suggest that there is some general alignment between theory and experience, which is in the slipstream of the theory. There are empirical studies dealing with more than half of the attributes proposed in theoretical papers as having an influence on elicitation techniques. Generally, the empirical papers tend to study attributes proposed by theoreticians, and only one attribute was studied in several empirical papers without being mentioned in theoretical proposals.

Further analysis of the empirical studies reveals that the confirmation of contextual attributes is poorly aligned, as the influence of contextual attributes was strongly confirmed only in one-third of the cases. This does not mean that the others do not influence elicitation but suggests that there may not have been enough or adequate empirical validations of their influence. Note that, due to the shortage of empirical studies, we were unable to study alignment at the technique-attribute level, even though it was an objective of interest, as this would have led to non-significant results.

Finally, we can say that even more empirical research is necessary for many of the attributes and, in this respect, an important contribution of this research is to provide researchers with guidance as to the future empirical studies in elicitation that should be conducted primarily in order to build an evidence-based body of knowledge on the elicitation process.

\section{Acknowledgement}

Research funded by the Spanish Ministry of Economy and Competitiveness research grant TIN2014-60490-P. 


\begin{tabular}{|c|c|c|c|c|c|c|c|}
\hline Factor & $\begin{array}{l}\text { Attributes (name } \\
\text { given in our } \\
\text { mapping study) }\end{array}$ & Study Type & Authors & $\begin{array}{l}\text { Original Name } \\
\text { (name given in the } \\
\text { primary study) }\end{array}$ & $\begin{array}{l}\text { Attributes Values } \\
\text { (discussed in the } \\
\text { primary study) }\end{array}$ & Excerpt/Results & $\begin{array}{l}\text { Primary } \\
\text { Study } \\
\text { Category }\end{array}$ \\
\hline \multirow[t]{13}{*}{ Elicitor } & \multirow[t]{3}{*}{$\begin{array}{l}\text { Information } \\
\text { Gathering } \\
\text { Experience }\end{array}$} & Theoretical & $\begin{array}{l}\text { Dhaliwal and } \\
\text { Benbazat, } \\
1990\end{array}$ & $\begin{array}{l}\text { Knowledge } \\
\text { Acquisition } \\
\text { Experience }\end{array}$ & No values & $\begin{array}{l}\text { This attribute can be } \\
\text { hypothesized to have a } \\
\text { potential impact on the } \\
\text { process of knowledge } \\
\text { acquisition }\end{array}$ & Framework \\
\hline & & \multirow[t]{2}{*}{ Empirical } & $\begin{array}{l}\text { Lloyd, Rosson, } \\
\text { and Arthur, } \\
2002\end{array}$ & $\begin{array}{l}\text { Requirements } \\
\text { Elicitation } \\
\text { Experience }\end{array}$ & Rating & $\begin{array}{l}\text { We discovered a rather weak } \\
\text { but positive relationship } \\
\text { between a group's average } \\
\text { requirements engineering } \\
\text { experience and the quality of } \\
\text { their' SRS documents }(\mathrm{FI})\end{array}$ & Experiment \\
\hline & & & $\begin{array}{l}\text { Agarwal and } \\
\text { Tanniru, } 1990\end{array}$ & $\begin{array}{l}\text { Knowledge } \\
\text { Acquisition } \\
\text { Experience }\end{array}$ & $\begin{array}{l}\text { Novice (academic } \\
\text { knowledge of problem } \\
\text { but no practitioner } \\
\text { experience), Experienced } \\
\text { (MIS practitioners with } \\
\text { at least one KA project or } \\
\text { at least } 3 \text { andears in } \\
\text { systems analysis) }\end{array}$ & $\begin{array}{l}\text { Two interview techniques } \\
\text { allowed novice knowledge } \\
\text { engineers to perform at a } \\
\text { level that was comparable to } \\
\text { experiences knowledge } \\
\text { engineers (AI) }\end{array}$ & Experiment \\
\hline & \multirow[t]{3}{*}{$\begin{array}{l}\text { Elicitation } \\
\text { Technique } \\
\text { Training }\end{array}$} & \multirow[t]{3}{*}{ Theoretical } & $\begin{array}{l}\text { Dhaliwal and } \\
\text { Benbazat, } \\
1990\end{array}$ & $\begin{array}{l}\text { Technical Knowl- } \\
\text { edge/Experience } \\
\text { with Specific } \\
\text { Elicitation } \\
\text { Methods }\end{array}$ & No values & $\begin{array}{l}\text { This attribute can be } \\
\text { hypothesized to have a } \\
\text { potential impact on the } \\
\text { process of knowledge } \\
\text { acquisition }\end{array}$ & Framework \\
\hline & & & $\begin{array}{l}\text { Davis and } \\
\text { Hickey, } 2003\end{array}$ & $\begin{array}{l}\text { Knowledge/ } \\
\text { Experience with } \\
\text { Specific } \\
\text { Elicitation } \\
\text { Techniques }\end{array}$ & No values & $\begin{array}{l}\text { The match between the } \\
\text { characteristics of the } \\
\text { bridge-builders and the } \\
\text { elicitation techniques used is } \\
\text { essential }\end{array}$ & Ontology \\
\hline & & & $\begin{array}{l}\text { Batista and } \\
\text { Carvalho, } \\
2003\end{array}$ & $\begin{array}{l}\text { Techniques Train- } \\
\text { ing/knowledge } \\
\text { Level }\end{array}$ & $\begin{array}{l}\text { Low, Medium, High, } \\
\text { Stranglehold }\end{array}$ & $\begin{array}{l}\text { The developer must know the } \\
\text { techniques to be used in the } \\
\text { elicitation process and must } \\
\text { undergo training }\end{array}$ & Taxonomy \\
\hline & \multirow[t]{7}{*}{$\begin{array}{l}\text { Domain } \\
\text { Familiarity }\end{array}$} & \multirow[t]{4}{*}{ Theoretical } & $\begin{array}{l}\text { Dhaliwal and } \\
\text { Benbazat, } \\
1990\end{array}$ & Domain Knowledge & No values & $\begin{array}{l}\text { This attribute can be } \\
\text { hypothesized to have a } \\
\text { potential impact on the } \\
\text { process of knowledge } \\
\text { acquisition }\end{array}$ & Framework \\
\hline & & & $\begin{array}{l}\text { Fowlkes et al, } \\
2000\end{array}$ & Domain Knowledge & No values & $\begin{array}{l}\text { Interviews may require } \\
\text { extensive domain knowledge }\end{array}$ & $\begin{array}{c}\text { Comparison of } \\
\text { techniques }\end{array}$ \\
\hline & & & $\begin{array}{l}\text { Davis et al, } \\
2006\end{array}$ & $\begin{array}{l}\text { Business } \\
\text { Knowledge }\end{array}$ & Known, Unknown & $\begin{array}{l}\text { Some technique allows analysts } \\
\text { to elicit requirements in } \\
\text { scenarios where they do not } \\
\text { have "business knowledge" }\end{array}$ & $\begin{array}{l}\text { Typology of } \\
\text { challenges }\end{array}$ \\
\hline & & & $\begin{array}{l}\text { Davis and } \\
\text { Hickey, } 2003\end{array}$ & $\begin{array}{l}\text { Experience in the } \\
\text { Problem Domain } \\
\text { and Application } \\
\text { Type }\end{array}$ & No values & $\begin{array}{l}\text { The match between the } \\
\text { characteristics of the } \\
\text { bridge-builders and the } \\
\text { elicitation techniques used is } \\
\text { essential }\end{array}$ & Ontology \\
\hline & & \multirow[t]{3}{*}{ Empirical } & $\begin{array}{l}\text { Hadar, Soffer } \\
\text { and Kenzi, } \\
2012\end{array}$ & Domain Knowledge & With and Without & $\begin{array}{l}\text { Analysts who had domain } \\
\text { knowledge presenting more } \\
\text { specific questions (FI) }\end{array}$ & Experiment \\
\hline & & & $\begin{array}{l}\text { Hadar, Soffer } \\
\text { and Kenzi, } \\
2012\end{array}$ & Perceived & Positive, Negative & $\begin{array}{l}\text { Domain knowledge supports } \\
\text { the communication between } \\
\text { the analyst and the } \\
\text { stakeholders. }\end{array}$ & Experiment \\
\hline & & & & $\begin{array}{l}\text { Effects of Domain } \\
\text { Knowledge }\end{array}$ & & $\begin{array}{l}\text { Domain knowledge can } \\
\text { positively as well as } \\
\text { negatively affect the } \\
\text { formation of the analyst's } \\
\text { deep understanding of the } \\
\text { customer's needs (FI) }\end{array}$ & \\
\hline
\end{tabular}




\begin{tabular}{|c|c|c|c|c|c|c|c|}
\hline Factor & $\begin{array}{l}\text { Attributes (name } \\
\text { given in our } \\
\text { mapping study) }\end{array}$ & Study Type & Authors & $\begin{array}{l}\text { Original Name } \\
\text { (name given in the } \\
\text { primary study) }\end{array}$ & $\begin{array}{l}\text { Attributes Values } \\
\text { (discussed in the } \\
\text { primary study) }\end{array}$ & Excerpt/Results & $\begin{array}{l}\text { Primary } \\
\text { Study } \\
\text { Category }\end{array}$ \\
\hline & & & $\begin{array}{l}\text { Niknafs and } \\
\text { Berry, } 2012\end{array}$ & $\begin{array}{l}\text { Mix of Domain } \\
\text { Familiarities }\end{array}$ & $\begin{array}{l}\text { Teams consisting of: } 3 \text { DIs } \\
\text { and } 0 \text { DAs, } 2 \text { DIs and } 1 \\
\text { DAs, } 1 \text { DIs and } 2 \text { DAs, } 0 \\
\text { DIs and } 3 \text { DAs. }\end{array}$ & $\begin{array}{l}\text { The mix of domain familiarities } \\
\text { in a team affects the quality } \\
\text { of the ideas generated by the } \\
\text { team (FI) }\end{array}$ & Experiment \\
\hline & Cognitive Aspects & Theoretical & $\begin{array}{l}\text { Batista and } \\
\text { Carvalho, } \\
2003\end{array}$ & Analist Abilities & Too much values & $\begin{array}{l}\text { Each technique requires a } \\
\text { developer's personal capacity }\end{array}$ & Taxonomy \\
\hline & & & $\begin{array}{l}\text { Tiwari, Rathore } \\
\text { and Gupta, } \\
2012\end{array}$ & Analyst Ability/Skill & $\begin{array}{r}\text { New, Less experience, } \\
\text { Experienced, Expert }\end{array}$ & $\begin{array}{l}\text { Analysts (elector) skill is one of } \\
\text { the key factors for selecting } \\
\text { requirement elicitation } \\
\text { techniques because the } \\
\text { requirement elicitation } \\
\text { process is highly affected by } \\
\text { the skills of analysts }\end{array}$ & Framework \\
\hline & & & $\begin{array}{l}\text { Davis and } \\
\text { Hickey, } 2003\end{array}$ & $\begin{array}{l}\text { Communication/ } \\
\text { Facilitation Skills }\end{array}$ & No values & $\begin{array}{l}\text { The match between the } \\
\text { characteristics of the } \\
\text { bridge-builders and the } \\
\text { elicitation techniques used is } \\
\text { essential }\end{array}$ & Ontology \\
\hline & & & $\begin{array}{l}\text { Tsumaki and } \\
\text { Tamai, } 2005\end{array}$ & $\begin{array}{l}\text { Requirements } \\
\text { Engineer Type }\end{array}$ & Logical, Imaginative & $\begin{array}{l}\text { The Requirement Engineer type } \\
\text { is a characteristic considered } \\
\text { in the authors' proposal }\end{array}$ & Framework \\
\hline & & Empirical & $\begin{array}{l}\text { Vale, } \\
\text { Albuquerque } \\
\text { and Beserra, } \\
2011\end{array}$ & Relevant skills & $\begin{array}{l}\text { Written communication } \\
\text { skills, Communication } \\
\text { skills, Ability to relate, } \\
\text { Ability to hear }\end{array}$ & $\begin{array}{l}\text { Skills and factors that may be } \\
\text { relevant for requirements } \\
\text { analysts can act effectively in } \\
\text { the role played (FI) }\end{array}$ & Survey \\
\hline \multirow[t]{8}{*}{ Informant } & $\begin{array}{l}\text { Number of } \\
\text { Informants }\end{array}$ & Theoretical & $\begin{array}{l}\text { Maiden and } \\
\text { Rugg, } 1996\end{array}$ & $\begin{array}{l}\text { Number of } \\
\text { Stakeholders }\end{array}$ & $1,2,6$ & $\begin{array}{l}\text { A framework is presented with } \\
\text { techniques that capture } \\
\text { requirements from different } \\
\text { number of stakeholders }\end{array}$ & Framework \\
\hline & & & $\begin{array}{l}\text { Kausar et al., } \\
2010\end{array}$ & $\begin{array}{l}\text { Number of } \\
\text { Stakeholders }\end{array}$ & Single, Multiple & $\begin{array}{l}\text { We need to identify the total } \\
\text { number of system } \\
\text { stakeholders for selecting the } \\
\text { right elicitation technique }\end{array}$ & Guidelines \\
\hline & & & $\begin{array}{l}\text { Davis and } \\
\text { Hickey, } 2003\end{array}$ & Stakeholder Count & None, One, Few, Many & $\begin{array}{l}\text { Inherent characteristics of all } \\
\text { the people involved in a } \\
\text { software development } \\
\text { project, especially they are } \\
\text { major drivers of the selection } \\
\text { of appropriate elicitation } \\
\text { techniques }\end{array}$ & Ontology \\
\hline & & Empirical & $\begin{array}{l}\text { Massey and } \\
\text { Wallace, } 1991\end{array}$ & Experts Number & Individuals, Group & $\begin{array}{l}\text { focus groups performed better } \\
\text { in generating "original" } \\
\text { responses than the individual } \\
\text { interview, and focus groups } \\
\text { were at least as good as } \\
\text { individual interviews in } \\
\text { terms of the "quality" and } \\
\text { "acceptance" of responses } \\
\text { (FI) }\end{array}$ & Experiment \\
\hline & $\begin{array}{l}\text { Stakeholder } \\
\text { Participation }\end{array}$ & Theoretical & $\begin{array}{l}\text { Tsumaki and } \\
\text { Tamai, } 2005\end{array}$ & User Involvement & Little, Much & $\begin{array}{l}\text { The user involvement is a } \\
\text { characteristic considered in } \\
\text { the authors' proposal }\end{array}$ & Framework \\
\hline & & & $\begin{array}{l}\text { Kausar et al., } \\
2010\end{array}$ & $\begin{array}{l}\text { Stakeholder } \\
\text { Involvement }\end{array}$ & $\begin{array}{l}\text { Maximum, Average, } \\
\text { Minimum }\end{array}$ & $\begin{array}{l}\text { we must know about } \\
\text { stakeholder position in the } \\
\text { organization and his/her } \\
\text { interest in the project for } \\
\text { selecting the right elicitation } \\
\text { technique }\end{array}$ & Guidelines \\
\hline & & & $\begin{array}{l}\text { Batista and } \\
\text { Carvalho, } \\
2003\end{array}$ & $\begin{array}{l}\text { User’ Participation } \\
\text { Level }\end{array}$ & Low, Medium, Hugh & $\begin{array}{l}\text { Some techniques require more } \\
\text { stakeholder participation }\end{array}$ & Taxonomy \\
\hline & & Empirical & $\begin{array}{l}\text { Lloyd, Rosson, } \\
\text { and Arthur, } \\
2002\end{array}$ & $\begin{array}{l}\text { Customer } \\
\text { Participation }\end{array}$ & Rating & $\begin{array}{l}\text { A weak positive trend was seen } \\
\text { between ratings (perception) } \\
\text { of customer participation and } \\
\text { overall SRS quality (FI) }\end{array}$ & Experiment \\
\hline
\end{tabular}




\begin{tabular}{|c|c|c|c|c|c|c|c|}
\hline Factor & $\begin{array}{l}\text { Attributes (name } \\
\text { given in our } \\
\text { mapping study) }\end{array}$ & Study Type & Authors & $\begin{array}{l}\text { Original Name } \\
\text { (name given in the } \\
\text { primary study) }\end{array}$ & $\begin{array}{l}\text { Attributes Values } \\
\text { (discussed in the } \\
\text { primary study) }\end{array}$ & Excerpt/Results & $\begin{array}{l}\text { Primary } \\
\text { Study } \\
\text { Category }\end{array}$ \\
\hline & \multirow[t]{6}{*}{$\begin{array}{l}\text { Geographical } \\
\text { Aspects }\end{array}$} & \multirow[t]{3}{*}{ Theoretical } & $\begin{array}{l}\text { Davis and } \\
\text { Hickey, } 2003\end{array}$ & $\begin{array}{l}\text { Temporal } \\
\text { Co-Location }\end{array}$ & Same time, Different time & $\begin{array}{l}\text { It captures whether or not the } \\
\text { technique demands that } \\
\text { participating parties be } \\
\text { located at the same physical } \\
\text { location, e.g., in the same } \\
\text { room }\end{array}$ & Ontology \\
\hline & & & $\begin{array}{l}\text { Davis and } \\
\text { Hickey, } 2003\end{array}$ & $\begin{array}{l}\text { Physical } \\
\text { Co-Location }\end{array}$ & Same place, Different place & $\begin{array}{l}\text { It captures whether or not the } \\
\text { technique demands that } \\
\text { participating parties be } \\
\text { located at the same physical } \\
\text { location, e.g., in the same } \\
\text { room }\end{array}$ & Ontology \\
\hline & & & Zhang, 2007 & Culture Diversity & National, Organizational & $\begin{array}{l}\text { Analysts shall using an } \\
\text { appropriate method to } \\
\text { interact wit } \mathrm{h} \\
\text { stakeholders from different } \\
\text { nationalities and } \\
\text { organizations }\end{array}$ & Framework \\
\hline & & \multirow[t]{3}{*}{ Empirical } & $\begin{array}{l}\text { Damian and } \\
\text { Zowghi, } 2002\end{array}$ & Cultural Diversity & $\begin{array}{l}\text { Cultural, Language, } \\
\text { Organizational, } \\
\text { Functional }\end{array}$ & $\begin{array}{l}\text { Differences in stakeholders' } \\
\text { language and national culture } \\
\text { affect global collaboration. } \\
\text { Equally important in this } \\
\text { case study was the impact of } \\
\text { differences in organizational } \\
\text { and functional culture (FI) }\end{array}$ & Case study \\
\hline & & & $\begin{array}{l}\text { Damian and } \\
\text { Zowghi, } 2002\end{array}$ & Time Difference & Synchronous, Asynchronous & $\begin{array}{l}\text { Hence asynchronous channels } \\
\text { were predominant in the } \\
\text { communication, } \\
\text { complemented by } \\
\text { teleconferencing calls. } \\
\text { Synchronous meetings across } \\
\text { continents are always } \\
\text { awkward for at least one site } \\
\text { - either too early or too late } \\
\text { in the day, and involve } \\
\text { someone having to } \\
\text { compromise on their work } \\
\text { schedule (FI) }\end{array}$ & Case study \\
\hline & & & $\begin{array}{l}\text { Lloyd, Rosson, } \\
\text { and Arthur, } \\
2002\end{array}$ & Synchronization & Synchronous, Asynchronous & $\begin{array}{l}\text { There is some suggestion that } \\
\text { synchronous collaboration in } \\
\text { the requirements process in } \\
\text { this study was possibly more } \\
\text { effective than asynchronous } \\
\text { collaboration (FI) }\end{array}$ & Experiment \\
\hline & \multirow[t]{4}{*}{$\begin{array}{l}\text { Information } \\
\text { Source }\end{array}$} & \multirow[t]{4}{*}{ Theoretical } & $\begin{array}{l}\text { Dhaliwal and } \\
\text { Benbazat, } \\
1990\end{array}$ & Stage of Expertise & No values & $\begin{array}{l}\text { The stage of development of an } \\
\text { expert has a direct impact on } \\
\text { his or her ability to articulate } \\
\text { expertise and thereby } \\
\text { influences both the choice of } \\
\text { the KA technique selected }\end{array}$ & Framework \\
\hline & & & Serna, 2012 & $\begin{array}{l}\text { Source of } \\
\text { Requirements }\end{array}$ & $\begin{array}{l}\text { Human being, other } \\
\text { envirements }\end{array}$ & $\begin{array}{l}\text { The font may be embedded in } \\
\text { people skills or physical } \\
\text { environments, requiring } \\
\text { different approaches to } \\
\text { capture them. }\end{array}$ & Framework \\
\hline & & & $\begin{array}{l}\text { Tiwari, Rathore } \\
\text { and Gupta, } \\
2012\end{array}$ & Type of End Users & $\begin{array}{l}\text { New user, Some knowledge } \\
\text { of domain, Domain } \\
\text { expert }\end{array}$ & $\begin{array}{l}\text { If the user has knowledge } \\
\text { about the domain then } \\
\text { always ask from users about } \\
\text { their expectation of the } \\
\text { system or about functionality } \\
\text { otherwise try to understand } \\
\text { users need by some other } \\
\text { mean }\end{array}$ & Framework \\
\hline & & & $\begin{array}{l}\text { Tiwari, Rathore } \\
\text { and Gupta, } \\
2012\end{array}$ & $\begin{array}{l}\text { Type of } \\
\text { Stakeholders }\end{array}$ & $\begin{array}{l}\text { Homogeneous, } \\
\text { Heterogeneous, Domain } \\
\text { expert, Not domain } \\
\text { expert but decision } \\
\text { maker }\end{array}$ & $\begin{array}{l}\text { To include all the stakeholders } \\
\text { in elicitation process is } \\
\text { required, so that any conflict } \\
\text { between them is resolved } \\
\text { and the requirements, which } \\
\text { will elicited are consistent } \\
\text { and reflect the actual needs } \\
\text { of the customer }\end{array}$ & Framework \\
\hline
\end{tabular}




\begin{tabular}{|c|c|c|c|c|c|c|c|}
\hline Factor & $\begin{array}{l}\text { Attributes (name } \\
\text { given in our } \\
\text { mapping study) }\end{array}$ & Study Type & Authors & $\begin{array}{l}\text { Original Name } \\
\text { (name given in the } \\
\text { primary study) }\end{array}$ & $\begin{array}{l}\text { Attributes Values } \\
\text { (discussed in the } \\
\text { primary study) }\end{array}$ & Excerpt/Results & $\begin{array}{l}\text { Primary } \\
\text { Study } \\
\text { Category }\end{array}$ \\
\hline & \multirow{4}{*}{ Articulacy } & \multirow[t]{2}{*}{ Empirical } & $\begin{array}{l}\text { Burton et al., } \\
1990\end{array}$ & Level of Expertise & $\begin{array}{l}\text { Novices (null experience), } \\
\text { Experts (experienced) }\end{array}$ & $\begin{array}{l}\text { Unlike experts, novices do not } \\
\text { show a characteristic pattern } \\
\text { of efficiency across } \\
\text { techniques (FI) }\end{array}$ & Experiment \\
\hline & & & $\begin{array}{l}\text { Todoran, Seyff } \\
\text { and Glinz, } \\
2013\end{array}$ & Target Audience & $\begin{array}{l}\text { Heterogeneous, No } \\
\text { Heterogeneous }\end{array}$ & $\begin{array}{l}\text { It was generally admitted that } \\
\text { the target audience for cloud } \\
\text { services is much more } \\
\text { heterogeneous than the } \\
\text { audience for traditional } \\
\text { software or hardware } \\
\text { products (FI) }\end{array}$ & Survey \\
\hline & & Theoretical & $\begin{array}{l}\text { Davis et al, } \\
2006\end{array}$ & $\begin{array}{r}\text { Articulability } \\
\text { Difficulties }\end{array}$ & No values & $\begin{array}{l}\text { Some technique allows analysts } \\
\text { to elicit requirements that } \\
\text { usually are not articulated by } \\
\text { users }\end{array}$ & $\begin{array}{l}\text { Typology of } \\
\text { challenges }\end{array}$ \\
\hline & & Empirical & Crandall, 1989 & $\begin{array}{l}\text { Verbalizations of } \\
\text { Knowledge }\end{array}$ & Quality cues & $\begin{array}{l}\text { Results from the present study } \\
\text { offer evidence that CDM } \\
\text { techniques can gain access to } \\
\text { aspects of expert knowledge } \\
\text { that are resistant to } \\
\text { articulation (FI) }\end{array}$ & Experiment \\
\hline & \multirow[t]{9}{*}{ Personal Aspects } & \multirow[t]{9}{*}{ Theoretical } & $\begin{array}{l}\text { Dhaliwal and } \\
\text { Benbazat, } \\
1990\end{array}$ & Cognitive Styles & No values & $\begin{array}{l}\text { Attribute of experts that impact } \\
\text { quality and efficiency of } \\
\text { knowledge acquisition } \\
\text { techniques }\end{array}$ & Framework \\
\hline & & & $\begin{array}{l}\text { Dhaliwal and } \\
\text { Benbazat, } \\
1990\end{array}$ & $\begin{array}{l}\text { Personality } \\
\text { Variables }\end{array}$ & No values & $\begin{array}{l}\text { Attribute of experts that impact } \\
\text { quality and efficiency of } \\
\text { knowledge acquisition } \\
\text { techniques }\end{array}$ & Framework \\
\hline & & & $\begin{array}{l}\text { Thew and } \\
\text { Sutcliffe, } \\
2008\end{array}$ & Motivations & $\begin{array}{l}\text { Power, Possession, } \\
\text { Achievement, } \\
\text { Self-esteem, Peer-esteem, } \\
\text { Self-efficacy, Curiosity, } \\
\text { Learning, Sociability, } \\
\text { Altruism }\end{array}$ & $\begin{array}{l}\text { Motivations are important for } \\
\text { understanding stakeholder } \\
\text { groups and for } \\
\text { individual-level requirements } \\
\text { when systems can be } \\
\text { customized or configured }\end{array}$ & Taxonomy \\
\hline & & & $\begin{array}{l}\text { Thew and } \\
\text { Sutcliffe, } \\
2008\end{array}$ & Values & $\begin{array}{l}\text { Trust, Sociability, } \\
\text { Morals/Ethics, Creativity, } \\
\text { Innovation, Aesthetics, } \\
\text { Security, Personal, } \\
\text { Characteristics, } \\
\text { Motivation, Beliefs \& } \\
\text { attitudes }\end{array}$ & $\begin{array}{l}\text { Value analysis may both alert } \\
\text { the analyst to potential } \\
\text { stakeholder conflicts, and } \\
\text { help the analyst better } \\
\text { understand the causes of } \\
\text { those conflicts }\end{array}$ & Taxonomy \\
\hline & & & $\begin{array}{l}\text { Thew and } \\
\text { Sutcliffe, } \\
2008\end{array}$ & Emotions & $\begin{array}{l}\text { Fear, Pleasure, Anxiety, } \\
\text { Frustration, Disgust, } \\
\text { Depression }\end{array}$ & $\begin{array}{l}\text { Understanding values and } \\
\text { emotions helps requirements } \\
\text { engineers interpret the } \\
\text { concerns held by individuals } \\
\text { and to predict their actions } \\
\text { and responses }\end{array}$ & Taxonomy \\
\hline & & & $\begin{array}{l}\text { Proynova et al., } \\
2010\end{array}$ & Personal Values & Attitudes & $\begin{array}{l}\text { But knowing the users' attitude } \\
\text { towards the tasks allows } \\
\text { deeper insight into the } \\
\text { requirements. Requirements } \\
\text { engineering (RE) process is } \\
\text { heavily influenced by soft } \\
\text { issues such as politics or } \\
\text { personal values of } \\
\text { stakeholders }\end{array}$ & Approach \\
\hline & & & Zhang, 2007 & $\begin{array}{l}\text { Cognitive } \\
\text { Limitations }\end{array}$ & $\begin{array}{l}\text { Ability of comprehension, } \\
\text { Capacity of memory and } \\
\text { recall, The information } \\
\text { processing activities, The } \\
\text { decision-making } \\
\text { processes }\end{array}$ & $\begin{array}{l}\text { The cognitive limitations vary } \\
\text { from people to people, so } \\
\text { different methods may be } \\
\text { suitable for different people } \\
\text { to elicit requirements within } \\
\text { the same context }\end{array}$ & Framework \\
\hline & & & $\begin{array}{l}\text { Byrd, Cossick } \\
\text { and Zmud, } \\
1992\end{array}$ & $\begin{array}{l}\text { Communication } \\
\text { Obstacles }\end{array}$ & Within, Between, Among & $\begin{array}{l}\text { Examinations of techniques and } \\
\text { how they are used to } \\
\text { overcome communications } \\
\text { obstacles and enrich } \\
\text { understanding }\end{array}$ & $\begin{array}{c}\text { Comparison of } \\
\text { techniques }\end{array}$ \\
\hline & & & $\begin{array}{l}\text { Aranda et al., } \\
2005\end{array}$ & $\begin{array}{c}\text { Stakeholders } \\
\text { Categories }\end{array}$ & $\begin{array}{l}\text { Visual, Verbal, Active, } \\
\text { Reflective }\end{array}$ & $\begin{array}{l}\text { It suggests an appropriate set } \\
\text { of groupware tools and } \\
\text { elicitation techniques } \\
\text { according to stakeholders' } \\
\text { preferences }\end{array}$ & Model \\
\hline
\end{tabular}




\begin{tabular}{|c|c|c|c|c|c|c|c|}
\hline Factor & $\begin{array}{l}\text { Attributes (name } \\
\text { given in our } \\
\text { mapping study) }\end{array}$ & Study Type & Authors & $\begin{array}{l}\text { Original Name } \\
\text { (name given in the } \\
\text { primary study) }\end{array}$ & $\begin{array}{l}\text { Attributes Values } \\
\text { (discussed in the } \\
\text { primary study) }\end{array}$ & Excerpt/Results & $\begin{array}{l}\text { Primary } \\
\text { Study } \\
\text { Category }\end{array}$ \\
\hline & & Empirical & $\begin{array}{l}\text { Corbridge et al., } \\
1994\end{array}$ & $\begin{array}{l}\text { Personality } \\
\text { Characteristics }\end{array}$ & $\begin{array}{l}\text { Extroversion/introversion, } \\
\text { Field depen- } \\
\text { dency/independency }\end{array}$ & $\begin{array}{l}\text { There was no evidence of effect } \\
\text { of personality characteristics } \\
\text { in this domain (AF) }\end{array}$ & Experiment \\
\hline & & & $\begin{array}{l}\text { Chao and } \\
\text { Salvendy, } \\
1995\end{array}$ & Cognitive Abilities & $\begin{array}{l}\text { Fluency, Induction, } \\
\text { Integrative processes, } \\
\text { Reasoning, Flexibility of } \\
\text { use }\end{array}$ & $\begin{array}{l}\text { Cognitive abilities of experts } \\
\text { affect significantly the } \\
\text { effectiveness of the elicited } \\
\text { data and the percentage of } \\
\text { total knowledge acquired (FI) }\end{array}$ & Experiment \\
\hline & & & Tan et al., 2010 & Consensus & Rating (\%) & $\begin{array}{l}\text { The focus group technique was } \\
\text { more effective than modified } \\
\text { Delphi method in achieving } \\
\text { consensus on ventilation } \\
\text { Management (FI) }\end{array}$ & Case study \\
\hline & & & $\begin{array}{l}\text { Chiravuri, } \\
\text { Nazareth, and } \\
\text { Ramamurthy, } \\
2011\end{array}$ & $\begin{array}{l}\text { Consensus Among } \\
\text { Experts }\end{array}$ & Rating & $\begin{array}{l}\text { RepGrid appears to be a } \\
\text { superior technique to reduce } \\
\text { disagreement and create } \\
\text { consensus in the long run } \\
\text { (FI) }\end{array}$ & Experiment \\
\hline \multirow[t]{7}{*}{$\begin{array}{l}\text { Problem } \\
\text { Domain }\end{array}$} & \multirow[t]{7}{*}{$\begin{array}{l}\text { Information } \\
\text { Types }\end{array}$} & \multirow[t]{7}{*}{ Theoretical } & $\begin{array}{l}\text { Maiden and } \\
\text { Rugg, } 1996\end{array}$ & $\begin{array}{l}\text { Observable } \\
\text { Phenomena }\end{array}$ & $\begin{array}{l}\text { Domain objects and } \\
\text { processes }\end{array}$ & $\begin{array}{l}\text { A framework is presented with } \\
\text { techniques that capture or } \\
\text { not observables phenomend }\end{array}$ & Framework \\
\hline & & & $\begin{array}{l}\text { Maiden and } \\
\text { Rugg, } 1996\end{array}$ & Knowledge Types & Behavior, Process, Data & $\begin{array}{l}\text { A framework is presented with } \\
\text { techniques that capture } \\
\text { different knowledge types }\end{array}$ & Framework \\
\hline & & & $\begin{array}{l}\text { Maiden and } \\
\text { Rugg, } 1996\end{array}$ & $\begin{array}{l}\text { Internal Filtering of } \\
\text { Knowledge }\end{array}$ & $\begin{array}{l}\text { Future system, Non-tacit, } \\
\text { Semi-tacit, Tacit }\end{array}$ & $\begin{array}{l}\text { A framework is presented with } \\
\text { techniques that acquire } \\
\text { knowledge about the existing } \\
\text { domain, requirements for the } \\
\text { new system, or both }\end{array}$ & Framework \\
\hline & & & Lauesen, 2002 & Information Types & $\begin{array}{l}\text { Current work, Current } \\
\text { problems, Goals and key } \\
\text { issues, Future system, } \\
\text { Realistic possibilities, } \\
\text { Consequences and risks, } \\
\text { Commitment, Conflict } \\
\text { Resolution, Requirements, } \\
\text { Priorities, Completeness }\end{array}$ & $\begin{array}{l}\text { It presents an assessment of } \\
\text { the adequacy of the } \\
\text { techniques for different types } \\
\text { of information requirements }\end{array}$ & Approach \\
\hline & & & Eva, 2001 & Knowledge Types & Non-tacit, Semi-tacit, Tacit & $\begin{array}{l}\text { The knowledge that RAD has to } \\
\text { address is more susceptible } \\
\text { to heuristic, iterative } \\
\text { approaches than to } \\
\text { traditional systems analysis } \\
\text { techniques. } \\
\text { The JRP/JAD workshop helps to } \\
\text { pull out tacit and semi-tacit } \\
\text { knowledge factors behind } \\
\text { certain of the requirements } \\
\text { as a necessary pre-requisite } \\
\text { for prototyping. } \\
\text { Traditional systems analysis, } \\
\text { which focused on automating } \\
\text { data processing, looked } \\
\text { mostly at non-tacit or } \\
\text { semi-tacit knowledge }\end{array}$ & $\begin{array}{c}\text { Comparison of } \\
\text { techniques }\end{array}$ \\
\hline & & & $\begin{array}{l}\text { Byrd, Cossick } \\
\text { and Zmud, } \\
1992\end{array}$ & $\begin{array}{l}\text { Problem Domain } \\
\text { Categories }\end{array}$ & $\begin{array}{l}\text { Information requirements, } \\
\text { Process understanding, } \\
\text { Behavior understanding, } \\
\text { Problem frame } \\
\text { understanding }\end{array}$ & $\begin{array}{l}\text { Proposal of matching between } \\
\text { certain elicitation techniques } \\
\text { and problems domain } \\
\text { categories }\end{array}$ & $\begin{array}{c}\text { Comparison of } \\
\text { techniques }\end{array}$ \\
\hline & & & Skidmore, 1994 & Knowledge Types & $\begin{array}{l}\text { Non-tacit, Semi-tacit, Tacit, } \\
\text { Taken-for-granted }\end{array}$ & $\begin{array}{l}\text { For the automation of data } \\
\text { processing tasks, these } \\
\text { generally proved satisfactory; } \\
\text { for providing Is support for } \\
\text { organizations that are } \\
\text { already computerized, and } \\
\text { where tacit and semi-tacit } \\
\text { knowledge is involved, they } \\
\text { are less helpful. Where a } \\
\text { Greenfield system is in } \\
\text { development, they are less } \\
\text { appropriate }\end{array}$ & Framework \\
\hline
\end{tabular}




\begin{tabular}{|c|c|c|c|c|c|c|c|}
\hline Factor & $\begin{array}{l}\text { Attributes (name } \\
\text { given in our } \\
\text { mapping study) }\end{array}$ & Study Type & Authors & $\begin{array}{l}\text { Original Name } \\
\text { (name given in the } \\
\text { primary study) }\end{array}$ & $\begin{array}{l}\text { Attributes Values } \\
\text { (discussed in the } \\
\text { primary study) }\end{array}$ & Excerpt/Results & $\begin{array}{l}\text { Primary } \\
\text { Study } \\
\text { Category }\end{array}$ \\
\hline & & \multirow{10}{*}{ Empirical } & Hua, 2008 & $\begin{array}{l}\text { Types of } \\
\text { Knowledge }\end{array}$ & $\begin{array}{l}\text { Concept, Process, Tacit, } \\
\text { Explicit }\end{array}$ & $\begin{array}{l}\text { It presents the various } \\
\text { techniques and shows the } \\
\text { types of knowledge } \\
\text { (tacit/Explicit, } \\
\text { concepts/processes) they are } \\
\text { mainly aimed at eliciting }\end{array}$ & $\begin{array}{c}\text { Comparison of } \\
\text { techniques }\end{array}$ \\
\hline & & & $\begin{array}{l}\text { Moody, Blanton } \\
\text { and Will, } \\
1999\end{array}$ & $\begin{array}{l}\text { Human Knowledge } \\
\text { Categories }\end{array}$ & $\begin{array}{l}\text { Declarative, Procedural, } \\
\text { Episodic, Semantic }\end{array}$ & $\begin{array}{l}\text { Matching knowledge elicitation } \\
\text { techniques with the human } \\
\text { knowledge categories }\end{array}$ & Framework \\
\hline & & & Zhang, 2007 & $\begin{array}{l}\text { Requirements } \\
\text { Abstraction Level }\end{array}$ & $\begin{array}{l}\text { Problem Analysis (It refers } \\
\text { to the business } \\
\text { requirements such as the } \\
\text { product vision, project } \\
\text { scope, and the } \\
\text { constraints), Product } \\
\text { description (It refers to } \\
\text { the product features } \\
\text { including functional and } \\
\text { nonfunctional } \\
\text { requirements) }\end{array}$ & $\begin{array}{l}\text { Taking into account the nature } \\
\text { of requirements on different } \\
\text { abstraction levels, a proper } \\
\text { set of elicitation methods } \\
\text { have to be chosen }\end{array}$ & Framework \\
\hline & & & $\begin{array}{l}\text { Kim and } \\
\text { Courtney, } \\
1988\end{array}$ & $\begin{array}{l}\text { Types of } \\
\text { Knowledge }\end{array}$ & $\begin{array}{l}\text { Concepts, Heuristics, } \\
\text { Reasoning }\end{array}$ & $\begin{array}{l}\text { Different Knowledge } \\
\text { Acquisition techniques elicit } \\
\text { these three types of } \\
\text { knowledge }\end{array}$ & $\begin{array}{c}\text { Comparison of } \\
\text { techniques }\end{array}$ \\
\hline & & & $\begin{array}{l}\text { Browne and } \\
\text { Rogich, } 2001\end{array}$ & $\begin{array}{l}\text { Generic } \\
\text { Requirements } \\
\text { Categories }\end{array}$ & $\begin{array}{l}\text { Goal level, Process level, } \\
\text { Task level, Information } \\
\text { level }\end{array}$ & $\begin{array}{l}\text { There were no significant } \\
\text { qualitative differences in the } \\
\text { types of requirements } \\
\text { elicited by each technique } \\
\text { (AF) }\end{array}$ & Experiment \\
\hline & & & $\begin{array}{l}\text { Scapolo and } \\
\text { Miles, } 2006\end{array}$ & $\begin{array}{l}\text { Types of } \\
\text { Knowledge and } \\
\text { Information }\end{array}$ & No values & $\begin{array}{l}\text { Different techniques, then, even } \\
\text { if based on soliciting experts } \\
\text { opinions through mean of } \\
\text { inquiries and applied on the } \\
\text { same topic, are likely to } \\
\text { achieve different levels and } \\
\text { types of knowledge and } \\
\text { information (FI) }\end{array}$ & Case study \\
\hline & & & $\begin{array}{l}\text { Grabowski, } \\
1988\end{array}$ & Heuristics Types & $\begin{array}{l}\text { Conceptual, Operational, } \\
\text { Logistics }\end{array}$ & $\begin{array}{l}\text { Techniques capture different } \\
\text { types of heuristic (FI) }\end{array}$ & Experiment \\
\hline & & & $\begin{array}{l}\text { McCloskey, } \\
\text { Geiwitz and } \\
\text { Kornell, } 1991\end{array}$ & Knowledge Types & $\begin{array}{l}\text { Evaluation dimension, Goal } \\
\text { dimension }\end{array}$ & $\begin{array}{l}\text { It revealed important } \\
\text { differences in the knowledge } \\
\text { elicited by the techniques (FI) }\end{array}$ & Experiment \\
\hline & & & $\begin{array}{l}\text { Moore and } \\
\text { Shipman, } \\
2000\end{array}$ & $\begin{array}{l}\text { Types of } \\
\text { Requirements }\end{array}$ & $\begin{array}{l}\text { High level functional, } \\
\text { Fine-grained procedural }\end{array}$ & $\begin{array}{l}\text { The most striking difference } \\
\text { between gathering textual } \\
\text { argumentation using a } \\
\text { questionnaire or GRC was the } \\
\text { type of information elicited. } \\
\text { The questionnaire process } \\
\text { produced mainly functional } \\
\text { information with little } \\
\text { information regarding } \\
\text { procedural details (FI) }\end{array}$ & Experiment \\
\hline & & & $\begin{array}{l}\text { Boulila, } \\
\text { Hoffmann } \\
\text { and } \\
\text { Herrmann, } \\
2011\end{array}$ & Type of Knowledge & Tacit knloledge, Non tacit & $\begin{array}{l}\text { Storytelling is a more effective } \\
\text { tool than brainstorming for } \\
\text { eliciting requirements and } \\
\text { including the tacit } \\
\text { knowledge as part of the } \\
\text { elicitation process (FI) }\end{array}$ & Experiment \\
\hline & \multirow[t]{3}{*}{ Domains Types } & Theoretical & $\begin{array}{l}\text { Coulin, Zowghi } \\
\text { and Sahraoui, } \\
2006\end{array}$ & $\begin{array}{l}\text { Type of Application } \\
\text { Domain }\end{array}$ & $\begin{array}{l}\text { Examples of application } \\
\text { domains include Business } \\
\text { Information, Group } \\
\text { Support, and Embedded } \\
\text { Control }\end{array}$ & $\begin{array}{l}\text { The general application domain } \\
\text { of the envisaged system is a } \\
\text { characteristic considered in } \\
\text { the authors' proposal }\end{array}$ & Approach \\
\hline & & & $\begin{array}{l}\text { Tsumaki and } \\
\text { Tamai, } 2005\end{array}$ & Domain Stability & Stable, Unstable & $\begin{array}{l}\text { The application domain type is } \\
\text { a characteristic considered in } \\
\text { the authors' proposal }\end{array}$ & Framework \\
\hline & & Empirical & $\begin{array}{l}\text { Burton et al., } \\
1990\end{array}$ & Domains Types & Flint, Pottery & $\begin{array}{l}\text { There is no significant } \\
\text { difference across domains } \\
\text { (AF) }\end{array}$ & Experiment \\
\hline
\end{tabular}




\begin{tabular}{|c|c|c|c|c|c|c|c|}
\hline Factor & $\begin{array}{l}\text { Attributes (name } \\
\text { given in our } \\
\text { mapping study) }\end{array}$ & Study Type & Authors & $\begin{array}{l}\text { Original Name } \\
\text { (name given in the } \\
\text { primary study) }\end{array}$ & $\begin{array}{l}\text { Attributes Values } \\
\text { (discussed in the } \\
\text { primary study) }\end{array}$ & Excerpt/Results & $\begin{array}{l}\text { Primary } \\
\text { Study } \\
\text { Category }\end{array}$ \\
\hline & \multirow[t]{7}{*}{ Uncertainty } & \multirow[t]{7}{*}{ Theoretical } & $\begin{array}{l}\text { Dhaliwal and } \\
\text { Benbazat, } \\
1990\end{array}$ & Uncertainty Degree & No values & $\begin{array}{l}\text { Attributes of the application } \\
\text { domain that impact quality } \\
\text { and efficiency of knowledge } \\
\text { acquisition techniques }\end{array}$ & Framework \\
\hline & & & $\begin{array}{l}\text { Davis and } \\
\text { Hickey, } 2003\end{array}$ & $\begin{array}{c}\text { Fuzziness of } \\
\text { Definition }\end{array}$ & No values & $\begin{array}{l}\text { Inherent characteristics of the } \\
\text { problem, including the } \\
\text { fuzziness of its definition } \\
\text { have a major impact on the } \\
\text { techniques that should be } \\
\text { used. }\end{array}$ & Ontology \\
\hline & & & $\begin{array}{l}\text { Davis et al, } \\
2006\end{array}$ & $\begin{array}{l}\text { Unknown Domain } \\
\text { Degree }\end{array}$ & No values & $\begin{array}{l}\text { Some technique provides } \\
\text { analysts and designers with a } \\
\text { clearer picture of the context } \\
\text { in which tasks are performed } \\
\text { by users } \\
\text { The RepGrid prompted a } \\
\text { discussion that revealed a } \\
\text { 'requirement' that was } \\
\text { previously 'unknown' to } \\
\text { either party }\end{array}$ & $\begin{array}{l}\text { Typology of } \\
\text { challenges }\end{array}$ \\
\hline & & & Serna, 2012 & Certainty Level & $\begin{array}{l}\text { Existing domain, New } \\
\text { Domain }\end{array}$ & $\begin{array}{l}\text { An important factor in } \\
\text { selecting a technique is the } \\
\text { level at which the } \\
\text { organization is familiar with } \\
\text { the application domain. }\end{array}$ & Framework \\
\hline & & & Zhang, 2007 & Level of Certainty & $\begin{array}{l}\text { New Domain, Existing } \\
\text { domain }\end{array}$ & $\begin{array}{l}\text { An important factor influences } \\
\text { on method selection is } \\
\text { whether the organization is } \\
\text { acquainted or unfamiliar } \\
\text { with the application domain. } \\
\text { An acquainted domain } \\
\text { implies a higher level of } \\
\text { certainty with the problem } \\
\text { than the new domain }\end{array}$ & Framework \\
\hline & & & $\begin{array}{l}\text { Kim and } \\
\text { Courtney, } \\
1988\end{array}$ & Structuredness & $\begin{array}{l}\text { Well-structured, } \\
\text { Semi-structured, } \\
\text { Ill-structured }\end{array}$ & $\begin{array}{l}\text { The model is based on the } \\
\text { arguments that the choice of } \\
\text { KA techniques is dependent } \\
\text { upon problem structuredness }\end{array}$ & $\begin{array}{c}\text { Comparison of } \\
\text { techniques }\end{array}$ \\
\hline & & & $\begin{array}{l}\text { Fazlollahi and } \\
\text { Tanniru, } 1991\end{array}$ & $\begin{array}{l}\text { Uncertainty/ } \\
\text { Equivocality } \\
\text { Degree }\end{array}$ & No values & $\begin{array}{l}\text { It calls for assessment of the } \\
\text { degree of uncertainty and } \\
\text { equivocality present in the } \\
\text { application and, based on } \\
\text { this, an appropriate } \\
\text { information acquisition } \\
\text { strategy is identified. }\end{array}$ & Approach \\
\hline & \multirow[t]{4}{*}{ Tasks Types } & Theoretical & $\begin{array}{l}\text { Dhaliwal and } \\
\text { Benbazat, } \\
1990\end{array}$ & Tasks Types & $\begin{array}{l}\text { Interpretation, Monitoring, } \\
\text { Prediction, Debugging, } \\
\text { Diagnosis, Repair, Design, } \\
\text { Instruction, Planning, } \\
\text { Control }\end{array}$ & $\begin{array}{l}\text { Within a specified domain, the } \\
\text { nature of the task selected } \\
\text { will affect the choice of KA } \\
\text { technique }\end{array}$ & Framework \\
\hline & & \multirow[t]{3}{*}{ Empirical } & \multirow[t]{2}{*}{$\begin{array}{l}\text { Wagner, Chung } \\
\text { and Najdawi, } \\
2003\end{array}$} & \multirow[t]{2}{*}{ Problem Types } & $\begin{array}{l}\text { Analysis problems } \\
\text { (Classification, } \\
\text { Debugging, Diagnosis, } \\
\text { Interpretation) }\end{array}$ & $\begin{array}{l}\text { It offers more tangible } \\
\text { evidence regarding the } \\
\text { possible linkages between } \\
\text { problem domains and KA } \\
\text { techniques (FI) }\end{array}$ & Case study \\
\hline & & & & & $\begin{array}{l}\text { Synthesis problems } \\
\text { (Configuration, Design, } \\
\text { Planning, Scheduling) } \\
\text { Combination problems } \\
\text { (Command and control, } \\
\text { Instruction, Monitoring, } \\
\text { Prediction, Repair) }\end{array}$ & & \\
\hline & & & $\begin{array}{l}\text { Massey and } \\
\text { Wallace, } 1991\end{array}$ & Scenarios & $\begin{array}{l}\text { Company president seeking } \\
\text { an additional credit line, } \\
\text { Company treasurer with } \\
\text { cash management } \\
\text { priorities, Dentist seeking } \\
\text { a loan to set up her own } \\
\text { practice. }\end{array}$ & $\begin{array}{l}\text { These mixed results imply that } \\
\text { there may be a relation } \\
\text { between the scenario (task), } \\
\text { and the performance of the } \\
\text { focus group and individual } \\
\text { interviews ( } \mathrm{FI} \text { ) }\end{array}$ & Experiment \\
\hline
\end{tabular}




\begin{tabular}{|c|c|c|c|c|c|c|c|}
\hline Factor & $\begin{array}{l}\text { Attributes (name } \\
\text { given in our } \\
\text { mapping study) }\end{array}$ & Study Type & Authors & $\begin{array}{l}\text { Original Name } \\
\text { (name given in the } \\
\text { primary study) }\end{array}$ & $\begin{array}{l}\text { Attributes Values } \\
\text { (discussed in the } \\
\text { primary study) }\end{array}$ & Excerpt/Results & $\begin{array}{l}\text { Primary } \\
\text { Study } \\
\text { Category }\end{array}$ \\
\hline & Problem Size & Theoretical & $\begin{array}{l}\text { Kim and } \\
\text { Courtney, } \\
1988\end{array}$ & $\begin{array}{l}\text { Number of } \\
\text { Elements }\end{array}$ & Small, Medium, Large & $\begin{array}{l}\text { The model is based on the } \\
\text { arguments that the choice of } \\
\text { KA techniques is dependent } \\
\text { upon problem size }\end{array}$ & $\begin{array}{c}\text { Comparison of } \\
\text { techniques }\end{array}$ \\
\hline & & & $\begin{array}{l}\text { Jiang and } \\
\text { Eberlein, } \\
2007\end{array}$ & Project Size & $\begin{array}{l}\text { Very small }(X<100 \\
\text { requirements), Small } \\
(100<=X<500) \text {, Medium } \\
(500<=X<1000) \text {, Big } \\
(1000<=X<4000) \text {, Very } \\
\text { big }(X>=4000)\end{array}$ & $\begin{array}{l}\text { Large projects require } \\
\text { systematic techniques to } \\
\text { elicit, analyze, document, } \\
\text { verify and validate } \\
\text { requirements. }\end{array}$ & Model \\
\hline & & & $\begin{array}{l}\text { Tsumaki and } \\
\text { Tamai, } 2005\end{array}$ & $\begin{array}{l}\text { Information } \\
\text { Resource Amount }\end{array}$ & Scarce, Abundant & $\begin{array}{l}\text { The available information is a } \\
\text { characteristic considered in } \\
\text { the authors' proposal }\end{array}$ & Framework \\
\hline & Complexity & Theoretical & $\begin{array}{l}\text { Kim and } \\
\text { Courtney, } \\
1988\end{array}$ & $\begin{array}{l}\text { Number of } \\
\text { Interrelationships }\end{array}$ & Simple, Moderate, Complex & $\begin{array}{l}\text { The model is based on the } \\
\text { arguments that the choice of } \\
\text { KA techniques is dependent } \\
\text { upon problem complexity }\end{array}$ & $\begin{array}{c}\text { Comparison of } \\
\text { techniques }\end{array}$ \\
\hline & & & $\begin{array}{l}\text { Jiang and } \\
\text { Eberlein, } \\
2007\end{array}$ & Project Complexity & $\begin{array}{l}\text { Very low, Low, Medium, } \\
\text { High, Very high }\end{array}$ & $\begin{array}{l}\text { A project with high complexity } \\
\text { requires systematic } \\
\text { techniques to be used in the } \\
\text { RE process. }\end{array}$ & Model \\
\hline & & & $\begin{array}{l}\text { Davis and } \\
\text { Hickey, } 2003\end{array}$ & Complexity & No values & $\begin{array}{l}\text { Inherent characteristics of the } \\
\text { problem, including the } \\
\text { fuzziness of its definition } \\
\text { have a major impact on the } \\
\text { techniques that should be } \\
\text { used. }\end{array}$ & Ontology \\
\hline & & Empirical & $\begin{array}{l}\text { Holsapple, Raj } \\
\text { and Wagner, } \\
2008\end{array}$ & Domain Complexity & Simple, Complex & $\begin{array}{l}\text { Regardless of the choice of KA } \\
\text { method, we do not have } \\
\text { conclusive evidence that } \\
\text { domain complexity st congly } \\
\text { affects KA efficiency. } \\
\text { However, as pointed out } \\
\text { earlier, the experiment does } \\
\text { suggest the direction of the } \\
\text { trend (FI) }\end{array}$ & Experiment \\
\hline & & & $\begin{array}{l}\text { Holsapple and } \\
\text { Raj, } 1994\end{array}$ & Domain Complexity & Simple, Complex & $\begin{array}{l}\text { Domain complexity does have } \\
\text { a bearing on the } \\
\text { performance of a knowledge } \\
\text { acquisition method (FI) }\end{array}$ & Experiment \\
\hline \multirow[t]{4}{*}{$\begin{array}{l}\text { Solution } \\
\text { Domain }\end{array}$} & Product Types & Theoretical & $\begin{array}{l}\text { Jiang and } \\
\text { Eberlein, } \\
2007\end{array}$ & Project Category & $\begin{array}{l}\text { Communication, } \\
\text { Embedded, } \\
\text { Semi-detached, Organic }\end{array}$ & $\begin{array}{l}\text { Projects in different categories } \\
\text { require different techniques } \\
\text { to be used in the RE process. } \\
\text { For example, the techniques } \\
\text { used in a safety-critical } \\
\text { system will not be the same } \\
\text { as the ones used in a } \\
\text { non-safety critical system. }\end{array}$ & Model \\
\hline & & & $\begin{array}{l}\text { Davis and } \\
\text { Hickey, } 2003\end{array}$ & Type of Solution & $\begin{array}{l}\text { Application, System, } \\
\text { Embedded software, } \\
\text { Custom development, } \\
\text { Customizing, } \\
\text { Commercial-off-the-shelf } \\
\text { software, Planning to } \\
\text { purchase, Build in-house }\end{array}$ & $\begin{array}{l}\text { The type of solution } \\
\text { anticipated may also impact } \\
\text { the selection of elicitation } \\
\text { techniques }\end{array}$ & Ontology \\
\hline & & & $\begin{array}{l}\text { Tiwari, Rathore } \\
\text { and Gupta, } \\
2012\end{array}$ & $\begin{array}{l}\text { Domain of the } \\
\text { System being }\end{array}$ & $\begin{array}{l}\text { New system domain, } \\
\text { Existing system domain }\end{array}$ & $\begin{array}{l}\text { Selection of elicitation } \\
\text { technique is influenced by } \\
\text { the nature (domain) of the } \\
\text { system, which will develop, } \\
\text { i.e. it means that whether we } \\
\text { developed system for a new } \\
\text { domain or for an existing } \\
\text { one domain. }\end{array}$ & Framework \\
\hline & & & $\begin{array}{l}\text { Tiwari, Rathore } \\
\text { and Gupta, } \\
2012\end{array}$ & $\begin{array}{l}\text { Developed } \\
\text { Scope of System }\end{array}$ & $\begin{array}{l}\text { Customize, System use } \\
\text { within an organization, } \\
\text { Generic product use, } \\
\text { Publicly }\end{array}$ & $\begin{array}{l}\text { The scope of the system mean } \\
\text { whether it is customized } \\
\text { (use of an organization } \\
\text { inside) or generic (use by } \\
\text { common users generally) is } \\
\text { affecting the selection of } \\
\text { elicitation techniques }\end{array}$ & Framework \\
\hline
\end{tabular}




\begin{tabular}{|c|c|c|c|c|c|c|c|}
\hline Factor & $\begin{array}{l}\text { Attributes (name } \\
\text { given in our } \\
\text { mapping study) }\end{array}$ & Study Type & Authors & $\begin{array}{l}\text { Original Name } \\
\text { (name given in the } \\
\text { primary study) }\end{array}$ & $\begin{array}{l}\text { Attributes Values } \\
\text { (discussed in the } \\
\text { primary study) }\end{array}$ & Excerpt/Results & $\begin{array}{l}\text { Primary } \\
\text { Study } \\
\text { Category }\end{array}$ \\
\hline & & & $\begin{array}{l}\text { Kausar et al., } \\
2010\end{array}$ & Target Stakeholder & $\begin{array}{l}\text { Market Need, Specific } \\
\text { Organizational Need }\end{array}$ & $\begin{array}{l}\text { The selection of elicitation } \\
\text { technique is dependent on } \\
\text { target stakeholder: if needs } \\
\text { have no well-defined } \\
\text { stakeholder (market) or if we } \\
\text { have defined set of } \\
\text { stakeholders (organizations) }\end{array}$ & Guidelines \\
\hline & & & $\begin{array}{l}\text { Kausar et al., } \\
2010\end{array}$ & Project Status & $\begin{array}{l}\text { New System, Existing } \\
\text { System }\end{array}$ & $\begin{array}{l}\text { Depending on whether the } \\
\text { system is new or existing we } \\
\text { select the appropriate } \\
\text { elicitation techniques }\end{array}$ & Guidelines \\
\hline & & & $\begin{array}{l}\text { Kausar et al., } \\
2010\end{array}$ & Type of Project & $\begin{array}{l}\text { Safety Critical Systems, } \\
\text { Security Critical Systems, } \\
\text { Real Time Systems, } \\
\text { Distributed Systems, } \\
\text { Interactive Systems, } \\
\text { Information Systems, } \\
\text { Small and medium sized } \\
\text { projects. }\end{array}$ & $\begin{array}{l}\text { We need to know about the } \\
\text { project type and nature, and } \\
\text { then on this basis we select } \\
\text { the suitable elicitation } \\
\text { technique and other } \\
\text { dependent properties }\end{array}$ & Guidelines \\
\hline & & Empirical & $\begin{array}{l}\text { Keil and } \\
\quad \text { Carmel, } 1995\end{array}$ & $\begin{array}{l}\text { Development } \\
\text { Environments }\end{array}$ & $\begin{array}{l}\text { Package (in which software } \\
\text { is developed as a product } \\
\text { for external sale), Custom } \\
\text { (in which software is } \\
\text { either developed } \\
\text { in-house or under } \\
\text { contract and is intended } \\
\text { for internal use) }\end{array}$ & $\begin{array}{l}\text { Given these differences, one } \\
\text { would expect to find } \\
\text { differences in the links that } \\
\text { are used across the two } \\
\text { environments (FI) }\end{array}$ & Case study \\
\hline & & & $\begin{array}{l}\text { Todoran, Seyff } \\
\text { and Glinz, } \\
2013\end{array}$ & $\begin{array}{l}\text { Mass Market } \\
\text { Systems }\end{array}$ & Cloud, Conventional & $\begin{array}{l}\text { Traditional approaches } \\
\text { (interviews, questionnaires, } \\
\text { analysis of existing } \\
\text { documentation, surveys) and } \\
\text { prototyping are the most } \\
\text { popular and highly applied } \\
\text { existing requirements } \\
\text { elicitation methods among } \\
\text { cloud providers (FI) }\end{array}$ & Survey \\
\hline & Criticality & Theoretical & $\begin{array}{l}\text { Jiang and } \\
\text { Eberlein, } \\
2007\end{array}$ & $\begin{array}{l}\text { Degree of Safety } \\
\text { Criticality }\end{array}$ & $\begin{array}{l}\text { (It measured by the } \\
\text { potential loss of human } \\
\text { life or property) Very } \\
\text { low, Low, Medium, High, } \\
\text { Very high }\end{array}$ & $\begin{array}{l}\text { Degree of safety criticality is } \\
\text { considered as an important } \\
\text { attribute for the selection of } \\
\text { RE techniques. Projects with } \\
\text { a high degree of safety } \\
\text { criticality require more } \\
\text { rigorous and disciplined } \\
\text { techniques. }\end{array}$ & Model \\
\hline & $\begin{array}{l}\text { Problem-Solving } \\
\text { Methods }\end{array}$ & Theoretical & $\begin{array}{l}\text { Moody, Blanton } \\
\text { and Will, } \\
1999\end{array}$ & $\begin{array}{l}\text { Representation of } \\
\text { Knowledge }\end{array}$ & $\begin{array}{l}\text { Rule-based, Frame-based, } \\
\text { Semantic Networks, } \\
\text { Case-based }\end{array}$ & $\begin{array}{l}\text { It provides a framework for } \\
\text { matching knowledge } \\
\text { elicitation techniques with } \\
\text { the representation of } \\
\text { knowledge in expert systems }\end{array}$ & Framework \\
\hline & & & $\begin{array}{l}\text { Dhaliwal and } \\
\text { Benbazat, } \\
1990\end{array}$ & $\begin{array}{l}\text { Methods of } \\
\text { Resolution }\end{array}$ & $\begin{array}{l}\text { Heuristic classification, } \\
\text { Heuristic configuration }\end{array}$ & $\begin{array}{l}\text { Attribute that impact quality } \\
\text { and efficiency of knowledge } \\
\text { acquisition techniques }\end{array}$ & Framework \\
\hline \multirow[t]{3}{*}{$\begin{array}{c}\text { Elicitation } \\
\text { Process }\end{array}$} & $\begin{array}{l}\text { Purpose of } \\
\text { Requirements }\end{array}$ & Theoretical & $\begin{array}{l}\text { Maiden and } \\
\text { Rugg, } 1996\end{array}$ & $\begin{array}{l}\text { Purpose of } \\
\text { Requirements }\end{array}$ & $\begin{array}{l}\text { Package selection, Bespoke } \\
\text { system, Requirements } \\
\text { procurement }\end{array}$ & $\begin{array}{l}\text { A framework is presented with } \\
\text { techniques that lead to } \\
\text { different purpose }\end{array}$ & Framework \\
\hline & & & Serna, 2012 & Level of Abstraction & $\begin{array}{l}\text { Problem analysis, Product } \\
\text { description }\end{array}$ & $\begin{array}{l}\text { Given the nature of the } \\
\text { requirements, at different } \\
\text { levels of abstraction must } \\
\text { select a suitable set of } \\
\text { elicitation techniques }\end{array}$ & Framework \\
\hline & Deliverable & Theoretical & $\begin{array}{l}\text { Coulin, Zowghi } \\
\text { and Sahraoui, } \\
2006\end{array}$ & Deliverable Type & $\begin{array}{l}\text { Examples of project } \\
\text { deliverables include } \\
\text { Requirements } \\
\text { Specification, } \\
\text { Concept of Operations, and } \\
\text { Vision \& Scope } \\
\text { documents. }\end{array}$ & $\begin{array}{l}\text { The required deliverable } \\
\text { document from the } \\
\text { elicitation project is a } \\
\text { characteristic considered in } \\
\text { the authors' proposal }\end{array}$ & Approach \\
\hline
\end{tabular}




\begin{tabular}{|c|c|c|c|c|c|c|c|}
\hline Factor & $\begin{array}{l}\text { Attributes (name } \\
\text { given in our } \\
\text { mapping study) }\end{array}$ & Study Type & Authors & $\begin{array}{l}\text { Original Name } \\
\text { (name given in the } \\
\text { primary study) }\end{array}$ & $\begin{array}{l}\text { Attributes Values } \\
\text { (discussed in the } \\
\text { primary study) }\end{array}$ & Excerpt/Results & $\begin{array}{l}\text { Primary } \\
\text { Study } \\
\text { Category }\end{array}$ \\
\hline & $\begin{array}{l}\text { Project } \\
\text { Environment }\end{array}$ & Theoretical & $\begin{array}{l}\text { Tiwari, Rathore } \\
\text { and Gupta, } \\
2012\end{array}$ & Social Environment & Low, Medium, High & $\begin{array}{l}\text { Most of the computer-based } \\
\text { system are developed } \\
\text { without any systematic help } \\
\text { of social science, the result of } \\
\text { this is that the needs of } \\
\text { users are not addressed } \\
\text { completely and there are } \\
\text { often serious misconceptions } \\
\text { are occurring. }\end{array}$ & Framework \\
\hline & \multirow[t]{2}{*}{$\begin{array}{l}\text { Elicitation Project } \\
\text { Type }\end{array}$} & Theoretical & $\begin{array}{l}\text { Coulin, Zowghi } \\
\text { and Sahraoui, } \\
2006\end{array}$ & $\begin{array}{l}\text { Type of Elicitation } \\
\text { Project }\end{array}$ & $\begin{array}{l}\text { Examples of project } \\
\text { definitions include } \\
\text { Custom Development, } \\
\text { COTS Selection, and } \\
\text { Feasibility Study. }\end{array}$ & $\begin{array}{l}\text { The definition of the type of } \\
\text { elicitation project being } \\
\text { conducted is a characteristic } \\
\text { considered in the authors' } \\
\text { proposal }\end{array}$ & Approach \\
\hline & & Empirical & $\begin{array}{l}\text { Zapata et al., } \\
\quad 2012\end{array}$ & $\begin{array}{l}\text { Software } \\
\text { Development } \\
\text { Scenarios }\end{array}$ & Distributed, Collocated & $\begin{array}{l}\text { The effectiveness of the } \\
\text { techniques in a co-located } \\
\text { setting is } 10 \% \text { higher than in } \\
\text { a distributed environment } \\
\text { (FI) }\end{array}$ & Experiment \\
\hline & \multirow[t]{5}{*}{$\begin{array}{l}\text { Communication } \\
\text { Types }\end{array}$} & \multirow[t]{5}{*}{ Empirical } & $\begin{array}{l}\text { Corbridge et al., } \\
1994\end{array}$ & Versions & Textual, Graphical, Tool & $\begin{array}{l}\text { The differences in the gain } \\
\text { elicited by the three versions } \\
\text { of laddering employed in this } \\
\text { study were statistically } \\
\text { significant (FI) }\end{array}$ & Experiment \\
\hline & & & $\begin{array}{l}\text { Rugg et al., } \\
1992\end{array}$ & Versions & Item, Cars, Label & $\begin{array}{l}\text { No significant differences were } \\
\text { found between the types of } \\
\text { knowledge elicited by } \\
\text { different types of sort (AF) }\end{array}$ & Experiment \\
\hline & & & $\begin{array}{l}\text { Ahmad, Tahir } \\
\text { and Kasirun, } \\
2012\end{array}$ & $\begin{array}{l}\text { Communication } \\
\text { Mode }\end{array}$ & $\begin{array}{l}\text { Face-to-Face, Rich Media, } \\
\text { Text-Based } \\
\text { Communication }\end{array}$ & $\begin{array}{l}\text { F2F has the highest level of } \\
\text { satisfaction, comfort, and } \\
\text { perceived } \\
\text { engagement, during the } \\
\text { negotiation and elicitation } \\
\text { stages, in } \\
\text { comparison to the other two } \\
\text { modes (FI) }\end{array}$ & Experiment \\
\hline & & & $\begin{array}{l}\text { Sauer, } \\
\text { Schramme } \\
\text { and } \\
\text { Rüttinger, } \\
2000\end{array}$ & Conference Types & $\begin{array}{l}\text { Face-to-face, Computer, } \\
\text { Multimedia }\end{array}$ & $\begin{array}{l}\text { The computer conference group } \\
\text { was generally more } \\
\text { productive than the two } \\
\text { other groups during the } \\
\text { conference (FI) }\end{array}$ & Experiment \\
\hline & & & $\begin{array}{l}\text { Todoran, Seyff } \\
\text { and Glinz, } \\
2013\end{array}$ & Meeeting Type & Remote, Physical & $\begin{array}{l}\text { The cloud calls for methods } \\
\text { which can be applied } \\
\text { remotely time (FI) }\end{array}$ & Survey \\
\hline & \multirow[t]{5}{*}{$\begin{array}{l}\text { Process } \\
\text { Constraints }\end{array}$} & \multirow[t]{5}{*}{ Theoretical } & $\begin{array}{l}\text { Maiden and } \\
\text { Rugg, } 1996\end{array}$ & $\begin{array}{l}\text { Time/Cost } \\
\text { Constraints }\end{array}$ & $\begin{array}{l}\text { Meeting is needed, Time to } \\
\text { prepare session, Time for } \\
\text { acquisition session, Time } \\
\text { to obtain requirements }\end{array}$ & $\begin{array}{l}\text { A framework is presented with } \\
\text { constraints that influence } \\
\text { techniques }\end{array}$ & Framework \\
\hline & & & $\begin{array}{l}\text { Kausar et al., } \\
2010\end{array}$ & Budget Constraints & Critical, High, Medium, Low & $\begin{array}{l}\text { Elicitation techniques should } \\
\text { be selected based on the } \\
\text { available budget }\end{array}$ & Guidelines \\
\hline & & & $\begin{array}{l}\text { Kausar et al., } \\
2010\end{array}$ & $\begin{array}{l}\text { Schedule } \\
\text { Constraints }\end{array}$ & Critical, High, Medium, Low & $\begin{array}{l}\text { Schedule has their own impact } \\
\text { and significance in the } \\
\text { project; few are strict } \\
\text { deadline specific while } \\
\text { others are less. The } \\
\text { elicitation techniques chosen } \\
\text { for strict deadline specific } \\
\text { projects should be short, } \\
\text { quick and effective. }\end{array}$ & Guidelines \\
\hline & & & $\begin{array}{l}\text { Kausar et al., } \\
\quad 2010\end{array}$ & $\begin{array}{l}\text { Resource } \\
\text { Constraints }\end{array}$ & Critical, High, Medium, Low & $\begin{array}{l}\text { The system resources factor } \\
\text { also has major impact on } \\
\text { elicitation technique } \\
\text { selection }\end{array}$ & Guidelines \\
\hline & & & Serna, 2012 & $\begin{array}{l}\text { Barriers in } \\
\text { Communication }\end{array}$ & $\begin{array}{l}\text { National culture, } \\
\text { Organizational Culture, } \\
\text { Cognitive limitation, } \\
\text { Geographically } \\
\text { distributed environment }\end{array}$ & $\begin{array}{l}\text { Because software development } \\
\text { projects are products of } \\
\text { global collaboration, } \\
\text { engineers face challenges } \\
\text { multinational organizations } \\
\text { to elicit requirements. }\end{array}$ & Framework \\
\hline
\end{tabular}




\begin{tabular}{|c|c|c|c|c|c|c|c|}
\hline Factor & $\begin{array}{l}\text { Attributes (name } \\
\text { given in our } \\
\text { mapping study) }\end{array}$ & Study Type & Authors & $\begin{array}{l}\text { Original Name } \\
\text { (name given in the } \\
\text { primary study) }\end{array}$ & $\begin{array}{l}\text { Attributes Values } \\
\text { (discussed in the } \\
\text { primary study) }\end{array}$ & Excerpt/Results & $\begin{array}{l}\text { Primary } \\
\text { Study } \\
\text { Category }\end{array}$ \\
\hline & & & $\begin{array}{l}\text { Jiang and } \\
\text { Eberlein, } \\
2007\end{array}$ & Time Constraints & $\begin{array}{l}\text { (Degree of the } \\
\text { time-to-market pressure } \\
\text { for the software project) } \\
\text { Very low, Low, Medium, } \\
\text { High, Very high }\end{array}$ & $\begin{array}{l}\text { Projects with high time } \\
\text { constraints require } \\
\text { lightweight techniques to be } \\
\text { used because heavy-weight } \\
\text { techniques will significantly } \\
\text { delay the overall project. }\end{array}$ & Model \\
\hline & & & $\begin{array}{l}\text { Jiang and } \\
\text { Eberlein, } \\
2007\end{array}$ & Cost Constraints & $\begin{array}{l}\text { (Ratio of the overall budget } \\
\text { of the project with } \\
\text { respect to its actual cost) } \\
\text { Very low, Low, Medium, } \\
\text { High, Very high }\end{array}$ & $\begin{array}{l}\text { Projects with high cost } \\
\text { constraints require } \\
\text { lightweight techniques to be } \\
\text { used in the RE process } \\
\text { because heavy-weight } \\
\text { techniques will increase the } \\
\text { cost, especially when training } \\
\text { for the use of the technique } \\
\text { is required. }\end{array}$ & Model \\
\hline & & Empirical & $\begin{array}{l}\text { Todoran, Seyff } \\
\text { and Glinz, } \\
2013\end{array}$ & Available Time & Less time, More time & $\begin{array}{c}\text { The cloud calls for methods } \\
\text { which take less time (FI) }\end{array}$ & Survey \\
\hline & \multirow[t]{3}{*}{ Process Moment } & \multirow[t]{3}{*}{ Theoretical } & $\begin{array}{l}\text { Zowghi and } \\
\text { Coulin, } 2005\end{array}$ & Activities & $\begin{array}{l}\text { Understanding domain, } \\
\text { Identifying requirements } \\
\text { sources, Analyzing } \\
\text { stakeholders, Selecting } \\
\text { techniques and } \\
\text { approaches, Eliciting } \\
\text { Requirements }\end{array}$ & $\begin{array}{l}\text { Its presents a guide to the use } \\
\text { of some techniques related to } \\
\text { the type of activity to } \\
\text { support }\end{array}$ & Guidelines \\
\hline & & & $\begin{array}{l}\text { Fowlkes et al, } \\
2000\end{array}$ & Analysis Job & No values & $\begin{array}{l}\text { Unstructured Interview is most } \\
\text { applicable early in job } \\
\text { analysis. Verbal protocols are } \\
\text { most applicable late in job } \\
\text { analysis. Structured interview } \\
\text { may be useful at any time } \\
\text { during a job analysis. }\end{array}$ & $\begin{array}{l}\text { Comparison KA } \\
\text { techniques }\end{array}$ \\
\hline & & & $\begin{array}{l}\text { Christel and } \\
\text { Kang, } 1992\end{array}$ & Early Tasks & $\begin{array}{l}\text { Fact-finding, Requirements } \\
\text { gathering, Evaluation and } \\
\text { rationalization, } \\
\text { Prioritization, Integration. }\end{array}$ & $\begin{array}{l}\text { It incorporates the advantages } \\
\text { of existing elicitation } \\
\text { techniques while } \\
\text { comprehensively addressing } \\
\text { the activities performed } \\
\text { during requirements } \\
\text { elicitation. }\end{array}$ & Methodology \\
\hline & \multirow[t]{2}{*}{ Methodologies } & \multirow[t]{2}{*}{ Theoretical } & $\begin{array}{l}\text { Tiwari, Rathore } \\
\text { and Gupta, } \\
2012\end{array}$ & Approach to be & Agile, IBIS, FODA etc. & $\begin{array}{l}\text { These methodologies force the } \\
\text { analyst to select a particular } \\
\text { elicitation technique for } \\
\text { elicitation process }\end{array}$ & Framework \\
\hline & & & $\begin{array}{l}\text { Dhaliwal and } \\
\text { Benbazat, } \\
1990\end{array}$ & $\begin{array}{l}\text { Followed out } \\
\text { System } \\
\text { Development } \\
\text { Methodology }\end{array}$ & No values & $\begin{array}{l}\text { Attribute that impact quality } \\
\text { and efficiency of knowledge } \\
\text { acquisition techniques }\end{array}$ & Framework \\
\hline
\end{tabular}




\section{References}

[1] H. Beyer, K. Holtzblatt, Apprenticing with the Customer, Commun. ACM 38 (5) (1995) 45-52.

[2] K. Pohl, Requirements Engineering: Fundamentals, Principles, and Techniques, Springer Publishing Company, 2010.

[3] J. Goguen, C. Linde, Techniques for Requirements Elicitation, in: Proceed ings of the IEEE International Symposium on Requirements Engineering, 1993, Pp. 152-164, doi:10.1109/ISRE.1993.324822.

[4] S. Sharma, S.K. Pandey, Revisiting requirements elicitation techniques, Int. J. Comput. Appl. 75 (12) (2013) 35-39.

[5] S. Khan, A.B. Dulloo, M. Verma, Systematic review of requirement elicitation techniques, Int. J. Inf. Comput. Technol. 4 (2) (2014) 133-138.

[6] B. Nuseibeh, S.M. Easterbrook, "Requirements engineering: a roadmap," The Future of Software Engineering, in: A.C.W. Finkelstein (Ed.), Proceedings of the 22nd International Conference on Software Engineering, ICSE'00, IEEE Computer Society Press, 2000.

[7] R.R. Hoffman, N. Shadbolt, A.M. Burton, G.A. Klein, Eliciting knowledge from experts: a methodological analysis, Organ. Behav. Human Dec. Proces. 62 (2) (1995) 129-158.

[8] H. Saiedian, R. Dale, Requirements engineering: making the connection between the software developer and customer, Inf. Softw. Technol. 42 (6) (2000) 419-428.

[9] A. Davis, O. Dieste, A. Hickey, N. Juristo, A.M. Moreno, Effectiveness of requirements elicitation techniques: empirical results derived from a systematic review, in: Proceedings of the 14th IEEE International Conference Requirements Engineering, 2006, pp. 179-188, doi:10.1109/RE.2006.17

[10] L. Macaulay, Requirements for Requirements Engineering Techniques, in: Proceedings of the Second International Conference Requirements Engineering (Cat. No.96TB100037), IEEE Comput. Soc. Press, Los Alamitos, CA, USA, 1996, pp. $157-164 . x v i+257$.

[11] S. Robertson, J. Robertson, Mastering the Requirements Process, Addison-Wesley, 1999.

[12] A. Davis, A. Hickey, Requirements researchers: do we practice what we preach, Requir. Eng. J. 7 (2) (2002) 107-111

[13] D. Zowghi and C. Coulin, Elicitation: a survey of techniques, approaches, and tools, A. Aurum, and C. Wohlin, eds., Engineering and Managing Software Requirements Springer-Verlag, New York, 2005, pp. 19-46.

[14] D. Carrizo, Comparison of research and practice regarding what we mean by" the right software requirements elicitation technique, in: Proceedings of the 10 th International Conference on the Quality of Information and Communications Technology (QUATIC), 2016.

[15] O. Dieste, N. Juristo, Systematic review and aggregation of empirical studies on elicitation techniques, IEEE Trans. Softw. Eng. 37 (2) (2010) 283-304, doi:10. 1109/TSE.2010.33

[16] D Carrizo, O. Dieste, N. Juristo, Systematizing requirements elicitation technique selection, Inf. Softw, Technol. 56 (6) (2014) 644-669.

[17] N. Maiden, G. Rugg, ACRE: selecting methods for requirements acquisition, Softw. Eng. J. 11 (3) (1996) 183-192.

[18] A. Davis, A. Hickey, A tale of two ontologies: the basis for systems analysis technique selection, in: Proceedings of the 9th Anmual American Conference on Information System (AMCIS 2003), Association for Information Systems, Atlanta, 2003, pp. 2968-2976.

[19] E. Batista, A Carvalho, Uma Taxonomia Facetada para Técnicas de Elicitação de Requisitos, in: Anais do WER03 - Workshop em Engenharia de Requisitos, 2003, pp. 48-62. http://wer.inf.puc-rio.br/wer03/artigos/edinelson_batista.pdf.

[20] E. Kheirkhah, A. Deraman, Important Factors in selecting requirements engineering techniques, in: Proceedings of the International Symposium on Information Technology (ITSim 2008), 2008, pp. 1-5, doi:10.1109/ITSIM.2008.4631895.

[21] B. Kitchenham, "Procedures for Performing Systematic Reviews," Technical Report TR/SE-0401 (420-46)-3, Keele University, 2004.

[22] D. Budgen, M. Turner, P. Brereton, B. Kitchenham, Using mapping studies in software engineering, in: Proceedings of the Psychology Programming Interest Group (PPIG 2008), Lancaster University, UK, 2008, pp. 195-204.

[23] K. Petersen, R. Feldt, S. Mujtaba, M. Mattsson, Systematic mapping studies in software engineering, in: Proceedings of the 12th International Conference on Evaluation and Assessment in Software Engineering, 2008, pp. 68-77.

[24] L. Jiang, A. Eberlein, Selecting requirements engineering techniques based on project attributes - a case study, in: Proceedings of the 14th Annual IEEE International Conference and Workshops on the Engineering of Computer-Based Systems, 2007, pp. 269-278, doi:10.1109/ECBS.2007.65.

[25] N. Cooke, Varieties of knowledge elicitation techniques, Int. J. Human Comput. Stud. 41 (6) (1994) 801-849.

[26] M. Roth, C. Wood, Knowledge acquisition from single versus multiple experts: a field study comparison using the Delphi technique, J. Knowl. Eng. 6 (3) (1993).

[27] S. Jones, J. Miles, M. Read, A Comparison of knowledge elicitation methods, Expert Syst. 13 (4) (1996) 277-295

[28] E. Hudlicka, Requirements elicitation with indirect knowledge elicitation techniques: comparison of three methods, in: Proceedings of the Second IEEE International Conference on Requirements Engineering, Los Alamitos, California, IEEE Computer Society Press, 1996, pp, 4-11.

[29] J.W. Moody, J.E. Blanton, P.H. Cheney, A theoretically grounded approach to assist memory recall during information requirements determination, J. Manag. Inf. Syst. 15 (1) (1998) 79-98
[30] L. Adelman, Measurement Issues in Knowledge Engineering, IEEE Trans. Sys tems Man Cybern. 19 (3) (1989) 483-488, doi:10.1109/21.31055.

[31] J.E. Fowlkes, E. Salas, D.P. Baker, The utility of event-based knowledge elicitation, Human Factors 42 (1) (2000) 24-35.

[32] B. Fazlollahi, M. Tanniru, Selecting a requirements determination methodolo gy-contingency approach revisited, Inf. Manag. 21 (5) (1991) 291-303.

[33] M. Christel and K. Kang, "Issues in Requirements Elicitation," Technical Report No: SEI-92-TR-012, Carnegie Mellon Software Engineering Institute, 1992.

[34] S. Lauesen, Software Requirements: Styles and Techniques, Addison-Wesley, 2002.

[35] T. Tsumaki, T. Tamai, Framework for matching requirements elicitation tech niques to project characteristics, Softw. Process Imp. Pract. 11 (5) (2006) 505-519.

[36] G.N. Aranda, A. Vizcainno, A. Cechich, M. Piattini, Choosing groupware tools and elicitation techniques according to stakeholders' features, in: Proceedings of the Seventh Intermational Conference on Enterprise Information Systems (ICEIS 2005), vol. 3, 2005, pp. 68-75.

[37] Z. Zhang, Effective requirements development - a comparison of requirements elicitation techniques, in: E. Berki, J. Nummenmaa, I. Sunley, M. Ross, G. Staples (Eds.), Software Quality Management XV: Software Quality in the Knowledge Society, British Computer Society, 2007, pp. 225-240.

[38] S. Thew, A. Sutcliffe, Investigating the Role of 'Soft Issues' in the RE Process, in: Proceedings of the 16th IEEE International Requirements Engineering Conference, Los Alamitos, IEEE Computer Society, 2008, pp. 63-66, doi:10.1109/RE 2008.35.

[39] R. Proynova, B. Paech, A. Wicht, T. Wetter, Use of personal values in require ments engineering - a research preview, in: Requirements Engineering: Foundation for Software Quality, Lecture Notes in Computer Science, 6182, 2010 pp. $17-22$.

[40] S. Kausar, S. Tariq, S. Riaz, A. Khanum, Guidelines for the Selection of Elicitation Techniques, in: Proceedings of the 6th International Conference on Emerging Technologies (ICET 2010), 2010, pp. 265-269, doi:10.1109/ICET.2010. 5638476.

[41] S. Tiwari, S.S. Rathore, A. Gupta, Selecting Requirement Elicitation Techniques for Software Projects, in: Proceedings of the Sixth International Conference on Software Engineering (CONSEG 2012), 2010, pp. 1-10, doi:10.1109/CONSEG.2012. 6349486.

[42] E. Serna, Analysis and selection to requirements elicitation techniques, in: Proceedings of the 7 th Colombian Computing Congress (CCC 2012), 2012, Pp. 1-7, doi:10.1109/ColombiancC.2u12.0sysuvi.

[43] J. Kim, J. Courtney, 3, A survey of knowledge acquisition techniques and their relevance to managerial problem domains, Dec. Supp. Syst. 4 (1988) 269-284.

[44] T.A. Byrd, K.L. Cossick, R.W. Zmud, A synthesis of research on requirements analysis and knowledge acquisition techniques, MIS Q. 16 (1) (1992) 117-138.

[45] JS. Dhaliwal, I. Benbazat, A framework for the comparative evaluation of knowledge acquisition tools and techniques, Knowl. Acquis. 2 (2) (1990) $145-166$.

[46] S. Skidmore, Introducing Systems Analysis, NCC/Blackwell, Manchester, 1994 pp. 74-85.

[47] C. Coulin, D Zowghi, A. Sahraoui, A Situational method engineering approach to requirements elicitation, Softw. Process Improv. Pract, 11 (5) (2006) $451-464$.

[48] J. Hua, Study on knowledge acquisition techniques, in: Proceedings of the 2nd International Symposium on Intelligent Information Technology Application (IITA 2008), vol. 1, 2008, pp. 181-185, doi:10.1109/IITA.2008.152.

[49] C.J. Davis, R.M. Fuller, M.C. Tremblay, D.J. Berndt, Communication challenges in requirements elicitation and the use of the repertory grid technique, J. Comp. Inform. Syst. 46 (5) (2006) 78-86.

[50] M. Eva, Requirements acquisition for rapid applications development, Inform. Manag. 39 (2) (2001) 101-107.

[51] M. Keil, E. Carmel, Customer-developer links, Commun. ACM 38 (5) (1995) $33-44$.

[52] J.M. Moore, F.M.I Shipman, a comparison of questionnaire based and GUI based requirements gathering, in: Proceedings of the Fifteenth IEEE International Conference on Automated Software Engineering, 35-43, 2000.

[53] D. Damian, D. Zowghi, The impact of stakeholders geographical distribution on managing requirements in a multi-site organization, in: Proceedings of the IEEE Joint International Conference on Requirements Engineering (RE'02), 2002 pp. $319-330$

[54] W.J. Lloyd, M.B. Rosson, J.D. Arthur, Effectiveness of elicitation techniques in distributed requirements engineering, in: Proceedings of the IEEE Joint Inter national Conference on Requirements Engineering, 2002, pp. 311-318, doi:10. 1109/ICRE.2002.1048544

[55] L. Vale, A.B. Albuquerque, P.V. Beserra, The importance of professional quality of requirements analysts for success of software development projects: a study to identify the most relevant skills, in: Proceedings of the 25th Brazilian Symposium on Software Enoineering (SBES 2011), 2011, pp. 253-262, doi:10.1109/SBES 2011.24

[56] N. Boulila, A. Hoffmann, A. Herrmann, Using storytelling to record requirements: elements for an effective requirements elicitation approach, in: Proceedings of the 4th International Workshop on Multimedia and Enjoyable Requirements Enginering - Beyond Mere Descriptions and with More Fun and Games (MERE'11), 2011, pp. 9-16, doi:10.1109/MERE.2011.6043945.

[57] S. Zapata, E. Torres, G. Sevilla, L. Aballay, M. Reus, Effectiveness of traditional software requirement elicitation techniques applied in distributed software de- 
velopment scenarios, in: Proceedings of the XXXVIII Latin American Conference of Informatic (CLEI 2012), 2012, pp. 1-7, doi:10.1109/CLEI.2012.6427200.

[58] I. Hadar, P. Soffer, K. Kenzi, The role of domain knowledge in requirements elicitation via interviews: an exploratory study, Requir. Eng. 19 (2) (2014) $143-159$.

[59] R. Ahmad, A. Tahir, Z.M. Kasirun, An empirical assessment of the use of different communication modes for requirement elicitation and negotiation: using students as a subject, in: Proceedings of the IEEE Symposium on Computers \& $\sigma^{\prime}$ Informatics (ISCI 2012), 2012, pp. 70-74, doi:10.1109/ICrI วn1) 6ว?2669.

[60] A. Niknafs, D.M. Berry, The Impact of domain knowledge on the effective ness of requirements idea generation during requirements elicitation, in: Pro ceedings of the 20th IEEE International Requirements Engineering Conference (RE 2012), 2012, pp. 181-190, doi:10.1109/RE.2012.6345802.

[61] I. Todoran, N. Seyff, M. Glinz, How cloud providers elicit consumer require ments: an exploratory study of nineteen companies, in: Proceedings of the 21st IEEE International Requirements Engineering Conference (RE 2013), 2013, pp. 105-114, doi:10.1109/RE.2013.6636710.

[62] M. Grabowski, Knowledge acquisition methodologies: survey and empirical assessment, in: Proceedings of the Ninth International Conference on Information Systems, 1988, pp. 47-54.

[63] B. Crandall, in: A comparative study of think aloud and critical decision knowledge elicitation methods, 108, 1989, pp. 144-146.

[64] A. Burton, N. Shadbolt, G. Rugg, A. Hedgecock, The efficacy of knowledge elicitation techniques: a comparison across domains and levels of expertise, Knowl Acquis. 2 (2) (1990) 167-178.

[65] B.P. McCloskey, J. Geiwitz, J. Kornell, Empirical comparisons of knowledge acquisition techniques, in: Proceedings of the Human Factors Society 35th Annual Meeting Human Factors Society, 1, Santa Monica, CA, USA, 1991, pp. 268-272.

[66] A.P. Massey, W.A. Wallace, Focus groups as a knowledge elicitation technique: an exploratory study, IEEE Trans. Knowl. Data Eng. 3 (2) (1991) 193-200, doi: $10.1109 / 69.87999$.

[67] G. Rugg, C. Corbridge, N.P. Major, A.M. Burton, N.R. Shadbolt, A comparison of sorting techniques in knowledge acquisition, Knowl. Acquis. 4 (3) (1992) $279-291$.
[68] B. Corbridge, G. Rugg, N.P. Major, N.R. Shadbolt, A.M. Burton, Laddering - technique and tool use in knowledge acquisition, Knowl. Acquis. 6 (1994) 315-341

[69] C.W. Holsapple, V.S. Raj, Exploratory study of two KA methods, Expert Syst. vol. 11 (2) (1994) $77-87$.

[70] C.J. Chao, G. Salvendy, Impact of cognitive abilities of experts on the effectiveness of elicited knowledge, Behav. Inf. Technol. 14 (3) (1995) 174-182.

[71] W. Wagner, Q. Chung, M. Najdawi, The impact of problem domains and knowledge acquisitions techniques: a content analysis of P/OM expert system case studies, Expert Syst. Appl. 24 (1) (2003) 79-86.

[72] C.W. Holsapple, V. Raj, W.P. Wagner, An experimental investigation of the impact of domain complexity on knowledge acquisition (KA) methods, Expert Syst. Appl. 35 (3) (2008) 1084-1094.

[73] K. Tan, G. Baxter, S. Newell, S. Smyec, P. Dear, K Brownlee, J. Darling, Knowledge elicitation for validation of a neonatal ventilation expert system utilising modified delphi and focus group techniques, Int. J. Human Comput. Stud. 68 (6) (2010) 344-354.

[74] R. Agarwal, M. Tanniru, Knowledge acquisition using structured interviewing: an empirical investigation, J. Manag. Inf. Syst. 7 (1) (1990) 123-140.

[75] G.J. Browne, M.B. Rogich, An empirical investigation of user requirements elicitation: comparing the effectiveness of prompting techniques, J. Manag. Inf. Syst. 17 (4) (2001) 223-249.

[76] F. Scapolo, I. Miles, Eliciting experts' knowledge: a comparison of two methods, Orig. Res. Article Technol. Forecast Social Ch. 73 (6) (2006) 679-704.

[77] J. Sauer, S. Schramme, B. Ruttinger, Knowledge acquisition in ecological product design: the effects of computer-mediated communication and elicitation method, Behav. Inf. Technol. 19 (5) (2000) 315-327.

[78] A. Chiravuri, D. Nazareth, K. Ramamurthy, Cognitive conflict and consensus generation in virtual teams during knowledge capture: comparative effectiveness of techniques, J. Manag. Inf. Syst. 28 (1) (2011) 311-350.

[79] D. Carrizo, O. Dieste, N. Juristo, Study of elicitation techniques adequacy, in: Proceedings of the XI Workshop on Requirements Engineering (WER 2008), 2008, pp. 104-114.

[80] B. Kitchenham, D. Budgen, P. Brereton, Evidence-based software engineering and systematic reviews, Innovations in Software Engineering and Software Development Series, 4, De Chapman \& Hall/CRC, 2015. 